\title{
Polymorphisms in Genes of Lipid Metabolism Are Associated with Type 2 Diabetes Mellitus and Periodontitis, as Comorbidities, and with the Subjects' Periodontal, Glycemic, and Lipid Profiles
}

\author{
Ingra G. Nicchio $\mathbb{D}^{1,2}$ Thamiris Cirelli $\mathbb{D}^{1,2}$ Rafael Nepomuceno $\mathbb{D}^{1,2}$ \\ Marco A. R. Hidalgo $₫{ }^{1,2}$ Carlos Rossa Jr. $₫,{ }^{1}$ Joni A. Cirelli $₫$, ${ }^{1}$ Silvana R. P. Orrico $\oplus^{1,},{ }^{1,3}$ \\ Silvana P. Barros $\mathbb{D},{ }^{4}$ Letícia H. Theodoro $\left(\mathbb{D},{ }^{5}\right.$ and Raquel M. Scarel-Caminaga $\mathbb{B}^{2}$ \\ ${ }^{1}$ Department of Diagnosis and Surgery, São Paulo State University-UNESP, School of Dentistry at Araraquara, Araraquara, \\ SP, Brazil \\ ${ }^{2}$ Department of Morphology, Genetics, Orthodontics and Pediatric Dentistry, São Paulo State University-UNESP, School of Dentistry \\ at Araraquara, Araraquara, SP, Brazil \\ ${ }^{3}$ Advanced Research Center in Medicine, Union of the Colleges of the Great Lakes (UNILAGO), São José do Rio Preto, \\ SP 15030-070, Brazil \\ ${ }^{4}$ Department of Periodontology, University of North Carolina at Chapel Hill-UNC, School of Dentistry, Chapel Hill, NC, USA \\ ${ }^{5}$ Department of Diagnosis and Surgery, São Paulo State University-UNESP, School of Dentistry at Araçatuba, Araçatuba, SP, Brazil
}

Correspondence should be addressed to Raquel M. Scarel-Caminaga; raquel.caminaga@unesp.br

Received 29 April 2021; Revised 25 August 2021; Accepted 19 October 2021; Published 11 November 2021

Academic Editor: Abdelaziz Amrani

Copyright (c) 2021 Ingra G. Nicchio et al. This is an open access article distributed under the Creative Commons Attribution License, which permits unrestricted use, distribution, and reproduction in any medium, provided the original work is properly cited.

\begin{abstract}
Background. Type 2 diabetes mellitus (T2DM) and periodontitis (P) commonly occur as comorbidities, but the commonalities in the genetic makeup of affected individuals is largely unknown. Since dyslipidemia is a frequent condition in these individuals, we investigate the association of genomic variations in genes involved in lipid metabolism with periodontal, glycemic, lipid profiles, and the association with periodontitis and T2DM (as comorbidities). Methods. Based on clinical periodontal examination and biochemical evaluation, 893 subjects were divided into T2DM+P (T2DM subjects also affected by periodontitis, $n=205$ ), periodontitis $(n=345)$, and healthy $(n=343)$. Fourteen single-nucleotide polymorphisms (SNPs) were investigated: LDLR gene (rs5925 and rs688), $A P O B$ (rs676210, rs1042031, and rs693), ABCC8 (rs6544718 and 6544713), LPL (rs28524, rs3735964, and rs1370225), HNF1A (rs2650000), APOE (rs429358 and rs7412), and HNF4A (rs1800961). Multiple linear and logistic regressions (adjusted for covariates) were made for all populations and stratified by sex and smoking habits. Results. Individuals carrying $A P O B$-rs1042031-CT (mainly women and never smokers) had a lower risk of developing periodontitis and T2DM $(\mathrm{T} 2 \mathrm{DM}+\mathrm{P})$; altogether, this genotype was related with healthier glycemic, lipid, and periodontal parameters. Significant disease-phenotype associations with gene-sex interaction were also found for carriers of $A P O B$-rs1676210-AG, HNF4A-rs1800961-CT, ABCC8-rs6544718-CT, LPL-rs13702-CC, and LPL-rs285-CT. Conclusions. Polymorphisms in lipid metabolism genes are associated with susceptibility to T2DM-periodontitis comorbidities, demonstrating gene-sex interaction. The $A P O B$-rs1042031 was the most relevant gene marker related to glucose and lipid metabolism profiles, as well as with obesity and periodontitis.
\end{abstract}

\section{Introduction}

Periodontitis $(\mathrm{P})$ is characterized by dysbiosis of the commensal microbiota associated with inflammation [1], which is responsible for the destruction of the hard and soft periodontal tissues that surround the tooth (connective gingival and alveolar bone tissue, cementum, periodontal ligament) causing dental mobility and culminating in tooth loss [2] It 
is considered the main cause of tooth loss in adults, affecting approximately $10-15 \%$ of the world population [3].

It derives from a complex and dynamic interplay among the immune system, microbiota, and lifestyle habits (e.g., smoking, and stress) ultimately resulting in homeostatic adaptation and maintenance of clinical health or disease manifestation. This interplay involves a highly complex network of host-derived molecules, which is largely determined by individual genomic variations. Individual genetic variations partly explain why manifestation of $\mathrm{P}$ often lacks correspondence with quality and amount of oral microbiota and also differs markedly between individuals with similar environmental backgrounds and comparable lifestyle habits [4].

Diabetes mellitus (DM) is a metabolic disorder that involves persistent hyperglycemia, resulting from defects in insulin production, insulin action, or both [5]. Type 2 diabetes mellitus (T2DM) occurs when there is a progressive loss of insulin secretion combined with insulin resistance $[6,7]$. Overwhelming evidence indicates that T2DM is associated with increased prevalence and severity of $\mathrm{P}$ [8]. In fact, $\mathrm{P}$ is currently acknowledged as the sixth "classical" complication of T2DM [9].

Dyslipidemia is a deregulation of lipid metabolism, characterized by qualitative and/or quantitative changes in plasma lipoproteins and lipids [10]. Dyslipidemia is highly prevalent in T2DM [11], and T2DM is considered to cause dyslipidemia [12] and T2DM and dyslipidemia are closely related to cardiovascular complications, an important cause of morbidity and mortality [13]. A meta-analysis [14] supports the association between $\mathrm{P}$ and dyslipidemia, as the occurrence of $\mathrm{P}$ is significantly associated with reduced HDL levels and elevated serum concentrations of LDL and triglycerides. Thus, it is conceivable that dyslipidemia has a role mediating the interaction between T2DM and $\mathrm{P}$, increasing the risks and severity of both conditions [15].

Periodontitis, T2DM, and dyslipidemia are complex conditions, which have in common their association with a systemic hyperinflammatory state [16]. In multifactorial diseases, genetic, epigenetic, and environmental factors play an essential role in their pathogenesis [17-19]. More studies are necessary to better understand the potential connection among P, T2DM, and dyslipidemia. Considering that the literature demonstrates a variety of genes relevant for dyslipidemia [20-28], we hypothesize that polymorphisms in genes of lipid metabolism could impact the occurrence of periodontitis alone or together with T2DM. Therefore, this study was aimed at investigating whether polymorphisms in lipid metabolism genes are associated with T2DM and periodontitis concomitantly present as comorbidities. Also, we investigate if specific genetic variants in these lipid metabolism genes are associated with glycemic and lipid profiles, as well with the periodontal status.

\section{Materials and Methods}

2.1. Study Subjects, Sample Collection, and DNA Isolation. A sample of 893 individuals with no familiar relations were included in the study from 1158 patients screened from the population who attended the Clinics of Periodontology, School of Dentistry at Araraquara, São Paulo State University (UNESP), Brazil, from 2010 to 2018. Subjects were excluded if they were younger than 30 years old, had chronic or systemic diseases (i.e., HIV infection or immunosuppressive chemotherapy), had received systemic antibiotics in the previous 3 months, were subjected to periodontal treatment in the previous 6 months, had less than 10 natural teeth (excluding third molars), and/or were pregnant or lactating.

The sample size was calculated with the G* Power Calculator, version 3.1.9 [29], as detailed in the Supplementary material. This study was approved by the Ethics in Human Research Committee of the School of Dentistry at Araraquara (UNESP; Protocol number 50/06) and followed the guidelines of the Helsinki Declaration of 1975 (revised in 1983).

The following biochemical parameters in the peripheral blood were determined for each participant: differential red and white blood cell count (ABX Micros 60); glycemic profile: insulin (chemiluminescence method), fasting glucose (modified Bondar and Mead method, Labtest Kit), and $\mathrm{HbAlc}$ (turbidimetric inhibition immunoassay method, Roche Kit); and lipid profiling: triglycerides (enzymaticTrinder method, Labtest Kit), total cholesterol (enzymaticTrinder method, Labtest Kit), HDL-cholesterol (high-density lipoprotein, enzymatic method, Labtest Kit), fractions of VLDL (very low-density lipoprotein), and LDLcholesterol (low-density lipoprotein), calculated according to the Friedewald equation [7, 30, 31]. Moreover, the patients underwent a physical examination to assess waist circumference $(\mathrm{cm})$, waist/hip ratio, body weight $(\mathrm{kg})$, and height $(\mathrm{m})$ to derive the body mass index (BMI) in $\mathrm{kg} / \mathrm{m}^{2}$.

A complete periodontal examination of all subjects assessed the following clinical signs and parameters at four interproximal sites around each tooth: probing pocket depth (PPDi) and clinical attachment level (CALi), measured to the nearest millimeter by a UNC-15 periodontal probe (Millennium ${ }^{\circledR}$ ) and the presence of visible plaque, marginal bleeding and bleeding on probing (BOP) [32, 33]. The last three parameters were registered as a percentage of the total number of interproximal sites assessed. All fully erupted teeth, except third molars and teeth with extensive destruction of the clinical crown, were examined. The criteria for the definition of periodontitis were according to the CDC/AAP (Centers for Disease Control and Prevention/American Academy of Periodontology) [4].

According to periodontal clinical examination and diagnosis of T2DM, the selected individuals were divided into three groups: T2DM+P (T2DM subjects also affected by periodontitis, $n=205)$, periodontitis $(n=345)$, and healthy ( $n=343$; no T2DM and no periodontitis). There were no individuals affected by only T2DM. Nondiabetics were considered as adequate when glycated hemoglobin $(\mathrm{HbAlc}) \leq$ $5.6 \%$ and fasting glucose levels $\leq 99 \mathrm{mg} / \mathrm{dL}$. Patients with periodontitis diagnosed by an endocrinologist as affected by T2DM were divided according to their glycemic metabolic control as poorly controlled (HbAlc $\geq 7.1 \%$; $n=123$ ) or well-controlled (HbAlc $\leq 7.0 \% ; n=82)$ [4]. 
TABLE 1: Information regarding the 14 investigated single-nucleotide polymorphisms (SNPs) in lipid metabolism genes.

\begin{tabular}{|c|c|c|c|c|}
\hline SNP & Assay ID & SNP position ${ }^{\dagger}$, alleles & Gene and classification of mutation & Call rate $(\%)^{*}$ \\
\hline rs5925 & C__2804279_10 & chr19:g.11230881T>C & $L D L R$ (silent mutation) & 96.92 \\
\hline rs688 & C___2804264_20 & chr19:g.11227602C $>\mathrm{T}$ & $L D L R$ (silent mutation) & 96.36 \\
\hline rs676210 & C__3216558_10 & chr11:g.21231524G>A & $A P O B$ (missense mutation) & 95.66 \\
\hline rs1042031 & C___7615381_20 & chr11:g.21225753C $>\mathrm{T}$ & $A P O B$ (silent mutation) & 96.22 \\
\hline rs693 & C__ 7615420_20 & chr11:g.21232195G>A & $A P O B$ (silent mutation) & 96.92 \\
\hline rs6544718 & C__25642779_10 & chr2:g.44104925T>A & $A B C C 8$ (missense variant) & 97.21 \\
\hline rs6544713 & C__26135636_10 & chr2:g.44073881T>C & $A B C C 8$ (intron variant) & 97.35 \\
\hline rs285 & C__12104266_10 & chr8:g.19815189C>T & $L P L$ (intron variant) & 96.65 \\
\hline rs3735964 & C__25800209_10 & chr8:g.19824045C>A & $L P L$ (3 prime UTR variant) & 96.51 \\
\hline rs13702 & C___9639448_10 & chr8:g.19824492T>A & $L P L$ (3 prime UTR variant) & 90.08 \\
\hline rs 2650000 & C__15874272_10 & chr12:g.121388962A $>C$ & HNF1A (intragenic) & 96.51 \\
\hline rs429358 & C__3 3084793_20 & chr19:g.45411941T>C & $A P O E$ (missense variant) & 97.35 \\
\hline rs7412 & C___904973_10 & chr19:g.45412079C $>\mathrm{T}$ & $A P O E$ (missense variant) & 97.35 \\
\hline rs 1800961 & C__ 7591528_10 & chr20:g.43042364C > T & HNF4A (missense variant) & 96.51 \\
\hline
\end{tabular}

${ }^{\dagger}$ Genome Reference Consortium Human Build 37 (GRCh37.p13) or hg19. * Represents the percentage of genotyping performed with success (all subjects).

A specific questionnaire confirmed smoking status. History of smoking was defined according to Miyake et al. as follows: (i) never smoked or (ii) ever smoked (including patients those who are current smokers and former smokers) [34].

Genomic DNA was extracted from buccal mucosa epithelial cells from each patient, using standard protocols involving proteinase $\mathrm{K}$ digestion, $8 \mathrm{M}$ ammonium acetate, and subsequent ethanol precipitation [35]. The purity of genomic DNA was assessed on a microvolume UV spectrophotometer (NanoDrop ${ }^{\circledR}$ 2000, Thermo Scientific) and quantified on a fluorometer (Qubit ${ }^{\circledR} 2.0$ fluorometer, Invitrogen). Samples were used whether they presented $\mathrm{A}_{260 / 280}$ ratio between 1.7 and 2.0, and the concentration was adjusted to $50 \mathrm{ng} / \mu \mathrm{L}$ in TE buffer (Tris- $\mathrm{HCl} 10 \mathrm{mM}$, EDTA $0.1 \mathrm{M}$, SDS $0.5 \%-\mathrm{pH} 8.0$ ).

2.2. Polymerase Chain Reaction (PCR) Amplification and $S N P$ Genotyping. The single-nucleotide polymorphisms (SNPs) in the LDLR (rs688, rs5925), APOB (rs676210, rs1042031, and rs676210), ABCC8 (rs6544718 and rs6544713), LPL (rs285, rs3735964, and rs13702), HNF1A (rs2650000), ApoE (rs429358 and rs7412), and HNF4A (rs1800961) genes, selected for this study, were genotyped by Real-Time Polymerase Chain Reaction (PCR) using Taq$\operatorname{Man}^{\circledR}$ (Thermo Fischer Scientific, Foster City, CA, EUA) systems. The amplification was performed in a final volume of $12.5 \mu \mathrm{L}$, containing $0.63 \mu \mathrm{L}$ of the specific TaqMan assay (Table 1) for genotyping each referred SNPs (including forward and reverse primers and probes marked with VIC and FAM), $6.25 \mu \mathrm{L}$ of TaqMan $^{\circledR}$ Genotyping Master Mix (2X TaqMan ${ }^{\circledR}$ Genotyping Master Mix, Thermo Fisher Scientific), $20 \mathrm{ng}$ of genomic DNA, and DNAse/RNAse free water in enough quantity to complete the final genotyping reaction. The following conditions were used for cycling the SNPs on a qPCR thermocycler (StepOnePlus Real-Time PCR System, Thermo Fisher Scientific): $95^{\circ} \mathrm{C}$ for 10 minutes, followed by 40 cycles of $95^{\circ} \mathrm{C}$ for 15 seconds, $60^{\circ} \mathrm{C}$ for $1 \mathrm{~min}$.
The genotyping analysis was performed with an online software (Applied Biosystems ${ }^{\mathrm{TM}}$ Analysis Software, Genotyping Analysis Module, version 3.2.).

2.3. Statistical Analysis. The general characteristics of each group were submitted to descriptive and analytical statistics using IBM SPSS Statistics 20.0 and GraphPad Prism 6.0. First, all data were evaluated by normality tests (D'Agostino-Pearson); then, they were applied with parametric (multiple comparisons with the one-way ANOVA followed by Tukey's test, expressed as the mean [ \pm standard deviation]) or nonparametric (multiple comparisons by KruskalWallis test followed by Dunn's test, expressed as the median minimum-maximum]) tests. Continuous demographic variables were compared among the groups using Student's $t$ -test (for age). The chi-squared test $\left(X^{2}\right)$ was used for categorical variables (sex, ethnicity, and smoking).

The Hardy-Weinberg equilibrium (HWE) formula was applied to the genotype frequencies, separately for each group, using chi-square goodness-of-fit for any deviations from the expected genotype equilibrium. A chi-squared test $\left(X^{2}\right)$ was also used to assess differences in genotypic and allelic distributions of each SNP between the groups of patients. All these analyses and the minor allele frequency (MAF) of each SNP were calculated using the PLINK software [36].

Multiple logistic regression models assuming additive allelic effects, adjusting for age, sex and smoking habits (as independent variables) were used for testing associations between SNPs and the occurrence of only P (when comparing healthy and periodontitis groups), the occurrence of only T2DM (when comparing periodontitis and $\mathrm{T} 2 \mathrm{DM}+\mathrm{P}$ groups), and the occurrence of T2DM together with $\mathrm{P}$ (when comparing healthy and $\mathrm{T} 2 \mathrm{DM}+\mathrm{P}$ groups). These gene-phenotype associations were estimated by the odds ratio (OR) and confidence interval (CI) of 95\%. The distributions of genotypes and alleles were compared in the two groups by chi-squared tests, and differences were considered significant when $p<0.05$. 
TABLE 2: Demographic characteristics of the studied groups, clinical periodontal parameters, glycemic and lipid profiles, and physical exams of all groups.

\begin{tabular}{|c|c|c|c|}
\hline & Healthy & Periodontitis & $\mathrm{T} 2 \mathrm{DM}+\mathrm{P}$ \\
\hline Demographic characteristics & $n=343$ & $n=345$ & $n=205$ \\
\hline Age, mean $( \pm S D)$ & $43( \pm 10.88)^{\mathrm{a}}$ & $49.06( \pm 9.29)^{\mathrm{b}}$ & $56.03( \pm 9.49)^{\mathrm{c}}$ \\
\hline \multicolumn{4}{|l|}{ Sex, $n(\%)$} \\
\hline Male & $110(32 \%)^{\mathrm{a}}$ & $204(59 \%)^{\mathrm{b}}$ & $86(42 \%)^{c}$ \\
\hline Female & $233(68 \%)^{\mathrm{a}}$ & $141(41 \%)^{b}$ & $119(58 \%)^{\mathrm{c}}$ \\
\hline \multicolumn{4}{|l|}{ Smoking habits, $n$ (\%) } \\
\hline Smoker & $29(8.45 \%)^{\mathrm{a}}$ & $34(9.85)^{\mathrm{a}}$ & $20(10 \%)^{\mathrm{a}}$ \\
\hline Former smoker & $47(13.7 \%)^{\mathrm{a}}$ & $89(25.8 \%)^{\mathrm{a}}$ & $64(31 \%)^{\mathrm{a}}$ \\
\hline Never smoker & $267(77.85 \%)^{\mathrm{a}}$ & $222(64.35 \%)^{\mathrm{b}}$ & $121(59 \%)^{\mathrm{b}}$ \\
\hline \multicolumn{4}{|c|}{ Periodontal parameters, mean $( \pm S D)$} \\
\hline Number of teeth & $25.5( \pm 3.43)^{\mathrm{a}}$ & $22.84( \pm 4.48)^{\mathrm{b}}$ & $20.54( \pm 5.51)^{\mathrm{C}}$ \\
\hline Visible plaque index (\% site) & $24.75( \pm 20.0)^{\mathrm{a}}$ & $54.82( \pm 28.13)^{\mathrm{b}}$ & $56.53( \pm 26.96)^{\mathrm{c}}$ \\
\hline Marginal bleeding (\% site) & $8.79( \pm 11.72)^{\mathrm{a}}$ & $20.07( \pm 23.25)^{\mathrm{b}}$ & $40.63( \pm 23.91)^{\mathrm{c}}$ \\
\hline BOPi (\% site) & $3.30( \pm 4.98)^{\mathrm{a}}$ & $39.98( \pm 23.17)^{\mathrm{b}}$ & $51.03( \pm 27.16)^{\mathrm{c}}$ \\
\hline $\mathrm{PPDi} \leq 4 \mathrm{~mm}$ (\% site $)$ & $99.93( \pm 0.30)^{\mathrm{a}}$ & $86.87( \pm 14)^{\mathrm{b}}$ & $79.11( \pm 22.69)^{\mathrm{c}}$ \\
\hline PPDi $\geq 5 \mathrm{~mm}$ (\% site) & $0.07( \pm 0.30)^{\mathrm{a}}$ & $13.13( \pm 14.0)^{\mathrm{b}}$ & $20.89( \pm 22.89)^{\mathrm{c}}$ \\
\hline CALi $\leq 3 \mathrm{~mm}(\%$ site $)$ & $99.49( \pm 0.78)^{\mathrm{a}}$ & $68.40( \pm 21.39)^{\mathrm{b}}$ & $56.22( \pm 27.32)^{\mathrm{c}}$ \\
\hline $\mathrm{CALi}=4-5 \mathrm{~mm}(\%$ site $)$ & $0.46( \pm 0.75)^{\mathrm{a}}$ & $20.07( \pm 11.92)^{\mathrm{b}}$ & $24.99( \pm 15.23)^{\mathrm{c}}$ \\
\hline $\mathrm{CALi} \geq 6 \mathrm{~mm}(\%$ site $)$ & $0.04( \pm 0.23)^{\mathrm{a}}$ & $11.53( \pm 13.68)^{\mathrm{b}}$ & $18.79( \pm 20.79)^{\mathrm{c}}$ \\
\hline \multicolumn{4}{|c|}{$\begin{array}{l}\text { Biochemical and physical data median } \\
\text { (minimum-maximum) }\end{array}$} \\
\hline Fasting blood glucose (mg/dL) & $91.50(80.0-99)^{\mathrm{a}}$ & $92(60.0-99)^{\mathrm{a}}$ & $152.2(83.0-467.9)^{\mathrm{b}}$ \\
\hline $\mathrm{HbA}_{1 \mathrm{c}}(\%)$ & $5.4(4.8-5.6)^{\mathrm{a}}$ & $5.6(4.4-5.60)^{\mathrm{a}}$ & $7.9(4.5-14.30)^{\mathrm{b}}$ \\
\hline Insulin $(\mathrm{UI} / \mathrm{mL})$ & $7.3(3.6-36.5)^{\mathrm{a}}$ & $9.8(4.1-31.3)^{\mathrm{a}}$ & $13.5(3.2-159.2)^{\mathrm{b}}$ \\
\hline Total cholesterol (mg/dL) & $176(134-218)^{\mathrm{a}}$ & $176(137-223)^{\mathrm{a}}$ & $192.5(139-306)^{\mathrm{b}}$ \\
\hline HDL-cholesterol (mg/dL) & $56(42-84)^{\mathrm{a}}$ & $53(30-88)^{\mathrm{a}}$ & $44(24-350.6)^{\mathrm{b}}$ \\
\hline LDL-cholesterol (mg/dL) & $96.40(50.6-155.8)^{\mathrm{a}}$ & $96.20(17.0-732.0)^{\mathrm{a}}$ & $109.8(7.9-525.0)^{\mathrm{a}}$ \\
\hline Triglycerides $(\mathrm{mg} / \mathrm{dL})$ & $104.4(41-283.8)^{\mathrm{a}}$ & $133(47.5-709.4)^{\mathrm{b}}$ & $156.2(33.9-765.0)^{\mathrm{b}}$ \\
\hline BMI $\left(\mathrm{kg} / \mathrm{m}^{2}\right)$ & $27.81(18.9-41.6)^{\mathrm{a}}$ & $26.9(18.21-37.9)^{\mathrm{a}}$ & $29.82(18.5-49.9)^{b}$ \\
\hline Waist-to-hip ratio $(\mathrm{cm})$ & $0.88(0.09-1.09)^{\mathrm{a}}$ & $0.91(0.74-1.07)^{\mathrm{a}}$ & $0.95(0.76-1.25)^{\mathrm{b}}$ \\
\hline
\end{tabular}

SD: standard deviation; BOPi: interproximal bleeding on probing; P: periodontitis; PPDi: interproximal probing pocket depth; CALi: interproximal clinical attachment level. Chi-squared test was used to determine differences among groups for sex and smoking habits. ${ }^{\mathrm{a}, \mathrm{b}, \mathrm{c}} \mathrm{D}$ Different letters means $p$ value $<0.05$; periodontal parameters were compared by one-way ANOVA, followed by Tukey's test. Biochemical and lipid levels were compared by Kruskal-Wallis test, followed by Dunn's test.

Furthermore, the same analysis was stratified by sex to identify the sex-specific effects of the SNPs on periodontitis by the additive model using multiple logistic regression adjusted by age and smoking. Similarly, to identify the effects of smoking habits with those SNPs on periodontitis, the population was stratified by smoking habits followed by the multiple logistic regressions adjusting by age and sex. Differences were considered significant when $p<0.05$, but whether the Bonferroni correction is considered, the experiment-wise significance is the $p$ value $<0.003$, as determined by the total number of genotyped markers in the study $(0.05 / 14$ SNPs).

Spearman's correlations among glycemic, lipid, and periodontal parameters were made for each group (Supplementary Figure 1). A multiple linear regression was used to assess the relationship of each SNP independently with periodontal parameters (number of remaining teeth, marginal bleeding, BOPi, PPDi, and CALi) and with glycemic, lipid, and obesity parameters (fasting glucose, insulin level, HbA1c, triglycerides, total cholesterol, HDL, LDL, BMI, and waist-to-hip ratio). All these analyses and multiple logistic regressions were performed using the STATA software version 12.0 for Windows (Statistics/Data Analysis, Stata Corporation, College Station, TX, USA).

\section{Results and Discussion}

3.1. Results. Regarding the demographic characteristics, there were statistical differences among the groups in the mean of age, sex, and smoking habits. Healthy individuals were younger (mean 43 y.o.) (Table 2). Most of the investigated population was composed by female and never- 
smoker subjects. The $\mathrm{T} 2 \mathrm{DM}+\mathrm{P}$ group showed the highest percentage of visible plaque index, marginal bleeding, interproximal bleeding on probing (BOPi), interproximal probing pocket depth (PPDi $\geq 5 \mathrm{~mm})$, and interproximal clinical attachment level (CALi $4-5 \mathrm{~mm}$ and CALi $\geq 6 \mathrm{~mm}$ ), demonstrating worse clinical periodontal condition when compared to periodontitis (without diabetes) group. The highest fasting glucose and $\mathrm{HbAlc}$ levels in the $\mathrm{T} 2 \mathrm{DM}+\mathrm{P}$ group are compatible with the T2DM diagnosis criteria. Total cholesterol and triglycerides levels were higher in the $\mathrm{T} 2 \mathrm{DM}+\mathrm{P}$ group, as well as the body mass index (BMI) and waist-to-hip ratio (Table 2). Collectively, these results support an association or clustering of obesity/dyslipide$\mathrm{mia} / \mathrm{T} 2 \mathrm{DM} /$ periodontitis in this studied population.

In the Supplementary Table 1, besides the allelic and genotypic distributions among the groups, it is possible to note that the majority of SNPs presented a minor allele frequency (MAF) greater than 0.05. The genotype distributions of each SNP did not deviate from the Hardy-Weinberg equilibrium in the healthy group.

We performed multiple logistic regression analyses, using the additive model, to assess the association of each SNP with the pathological phenotype: periodontitis or T2DM together with P (T2DM+P) (Table 3). In the comparison between the healthy group versus Periodontitis, only the rs285 SNP ( $L P L$ gene) was significant, since heterozygous (CT) men had a 56\% lower chance to develop periodontitis $\quad(\mathrm{OR}=0.44, \quad 95 \% \quad \mathrm{CI}: \quad 0.23-0.85, \quad p=0.01)$. Regarding the gene variation in the $\mathrm{T} 2 \mathrm{DM}+\mathrm{P}$ versus healthy, only the rs1042031 SNP in the APOB gene was statistically significant, as individuals with the CT genotype had a significantly lower chance to develop T2DM and periodontitis (adjusted OR 0.47, 95\% CI: 0.28-0.77, $p=0.003$ ) after Bonferroni correction. Female gender (adjusted OR 0.34, 95\% CI: $0.18-0.65, p=0.001)$ and never smoking subjects (adjusted OR 0.40, 95\% CI: 0.21-0.75, $p=0.004$ ) also were associated with reduced risk of $\mathrm{T} 2 \mathrm{DM}+\mathrm{P}$. Even in the never-smoking female subjects, the APOB-rs1042031-CT genotype was still significantly associated with a lower chance of developing periodontitis and T2DM (adjusted OR $0.31,95 \%$ CI: $0.15-0.69, p=0.004)$. In the same $A P O B$ gene, never smokers carrying the rs676210-AG SNP had increased risk of $\mathrm{T} 2 \mathrm{DM}+\mathrm{P}$ (adjusted $\mathrm{OR}=1.85,95 \% \mathrm{CI}$ : $1.06-3.20, p=0.03)$. Regarding the $A B C C 8$ gene, men carrying the rs6544718-CT also showed less chance $(63 \%)$ to develop $\mathrm{T} 2 \mathrm{DM}+\mathrm{P} \quad(\mathrm{OR}=0.37 ; 95 \% \mathrm{CI}=0.16-0.83 ; p=$ 0.01 ). Homozygous (CC) men for the rare allele in the rs13702 ( $L P L$ gene) were more susceptible to $\mathrm{T} 2 \mathrm{DM}+\mathrm{P}$ (adjusted OR 4.38, 95\% CI: 1.52-12.58, $p=0.006$ ). Increased risk of periodontitis was also observed for all subjects carrying the rs180096-CT (HNF4A gene), since they were almost twice more susceptible to the development of $\mathrm{T} 2 \mathrm{DM}+\mathrm{P}$ $(\mathrm{OR}=1.96 ; 95 \% \mathrm{CI}=1.01-3.80 ; p=0.04)$ (Table 3).

Additional result analyses in the different groups are presented in the Supplementary material. Supplementary Figure 1 shows Spearman's correlations of biochemical and periodontal data in each studied group. In Supplementary Table 2, we present data of median (minimum-maximum) of glycemic and lipid profiles and physical exams of individuals belonging to the $\mathrm{T} 2 \mathrm{DM}+\mathrm{P}$ subgroups. In this Supplementary Table 2, when we subdivided T2DM+P by the severity of periodontitis, and we compared wellcontrolled $\mathrm{T} 2 \mathrm{DM}+\mathrm{P}$ with poorly controlled $\mathrm{T} 2 \mathrm{DM}+\mathrm{P}$, we observed that the patients with severe periodontitis presented, in general, a higher glycemic and lipid biochemical levels. For example, poorly controlled with severe periodontitis $\mathrm{T} 2 \mathrm{DM}+\mathrm{P}$ patients showed the highest levels of fasting glucose and HbAlc.

When we considered T2DM_P moderate versus severe periodontitis patients compared by their lipid parameters, we observed in dyslipidemic T2DM patients with severe P statistically significant higher levels of total cholesterol, LDL-cholesterol, and triglycerides, suggesting that the severity of P could be related with the worst lipid profile of the patients.

Multiple linear regression analyses indicate that the $A P O B$-rs1042031-CT was related to the number of remaining teeth $(\beta=-0.08 ; p=0.017)$, bleeding on probing $(\beta=-0.05 ; p=0.03), \mathrm{PPDi} \geq 5 \mathrm{~mm}(\beta=-0.08 ; p=0.008)$, and CALi $\geq 6 \mathrm{~mm}(\beta=-0.07 ; p=0.01)$ (Table 4). A negative coefficient suggests that as the independent variable increases, the dependent variable tends to decrease, thus supporting a possible protective role for this SNP in periodontitis. In contrast, the rs676210-AG SNP in the same $A P O B$ gene was positively associated with bleeding on probing $(\beta=0.05 ; p=0.02)$ and CALi $\geq 6 \mathrm{~mm}(\beta=0.07 ; p=0.01$ ). The SNP rs5925 (LDLR gene) was significantly related to marginal bleeding $(\beta=-0.17 ; p=0.02)$, which may suggest an influence on immune response to oral biofilm bacteria. Multiple linear regression analyses assessing the association of each SNP with biochemical and obesity parameters (Table 5) also detected the APOB-rs1042031-CT SNP as relevant for glycemic, lipid, and obesity parameters, particularly the waist-to-hip ratio $(\beta=-0.25 ; p \leq 0.01)$. The rs676210-AA SNP in the same $A P O B$ gene was positively related to fasting glucose $(\beta=0.21 ; p=0.03)$, supporting a role for this genetic variation in T2DM. The rs285 SNP ( $L P L$ gene) was also related to BMI and to waist-to-hip ratio (Table 5). Results of Spearman's correlations between biochemical profiles and periodontal parameters for each group can be found in the Supplementary Figure 1.

3.2. Discussion. This case-control study demonstrates the association of polymorphisms in genes relevant for lipid metabolism with the occurrence of periodontitis $(\mathrm{P})$ or the occurrence of T2DM and P concomitantly $(\mathrm{T} 2 \mathrm{DM}+\mathrm{P})$. Specifically, the rs1042031 SNP in the $A P O B$ gene and the rs6544718 SNP in the ABCC8 gene were protective, as their presence is associated with a significantly lower risk of $\mathrm{T} 2 \mathrm{DM}+\mathrm{P}$. In contrast, the $\operatorname{rs676210}(A P O B), \operatorname{rs} 13702$ $(L P L)$, and rs1800961 (HNF4A) SNPs were associated with increased risk of $\mathrm{T} 2 \mathrm{DM}+\mathrm{P}$. There was no significant association between SNPs in $L D L R$ and APOE genes with either P or $\mathrm{T} 2 \mathrm{DM}+\mathrm{P}$ in Brazilian subjects.

Polymorphisms in the $A P O B$ gene have been associated with variability in serum cholesterol levels and coronary atherosclerosis in some populations [37, 38]. The rs1042031 SNP involves a silent mutation from cytosine to thymine 
TABLE 3: Multiple logistic regression analyses for all patients (adjusted by age, sex, and smoking), for patients stratified by sex ${ }^{\ddagger}$ (adjusted by age and smoking) and by smoking habits (adjusted by age and sex). Chi-squared test $\left(X^{2}\right)$ for genotypic and allelic distributions.

(a)

\begin{tabular}{|c|c|c|c|c|c|c|}
\hline \multirow{2}{*}{$\begin{array}{l}\text { Gene } \\
\text { SNP } \\
\text { LDLR }\end{array}$} & \multicolumn{2}{|c|}{ Healthy versus periodontitis } & \multicolumn{2}{|c|}{ Healthy versus $\mathrm{T} 2 \mathrm{DM}+\mathrm{P}$} & \multicolumn{2}{|c|}{ Periodontitis versus $\mathrm{T} 2 \mathrm{DM}+\mathrm{P}$} \\
\hline & Adj OR (95\% CI) & $p$ value & Adj OR $(95 \%$ CI $)$ & $p$ value & Adj OR (95\% CI) & $p$ value \\
\hline \multicolumn{7}{|l|}{$r s 5925$} \\
\hline All patients ${ }^{\dagger}$ & Adjusted $\mathrm{OR}^{\dagger}$ & & Adjusted $\mathrm{OR}^{\dagger}$ & & Adjusted $\mathrm{OR}^{\dagger}$ & \\
\hline TT & Ref & & Ref & & Ref & \\
\hline CT & $0.96(0.68-1.36)$ & 0.81 & $1.01(0.62-1.62)$ & 0.97 & $1.13(0.73-1.75)$ & 0.58 \\
\hline $\mathrm{CC}$ & $0.92(0.58-1.46)$ & 0.72 & $1.12(0.60-2.06)$ & 0.71 & $1.02(0.58-1.79)$ & 0.93 \\
\hline \multicolumn{7}{|l|}{$X^{2}$} \\
\hline Genotype & 0.096 & & 0.355 & & 0.183 & \\
\hline Allele & 0.031 & & 0.003 & & 0.041 & \\
\hline Male $^{\ddagger}$ & Adjusted $\mathrm{OR}^{\ddagger}$ & & Adjusted $\mathrm{OR}^{\ddagger}$ & & Adjusted $\mathrm{OR}^{\ddagger}$ & \\
\hline TT & Ref & & Ref & & Ref & \\
\hline $\mathrm{CT}$ & $1.31(0.73-2.37)$ & 0.36 & $1.21(0.50-2.89)$ & 0.67 & $1.15(0.56-2.36)$ & 0.70 \\
\hline $\mathrm{CC}$ & $1.13(0.51-2.50)$ & 0.76 & $2.50(0.80-7.82)$ & 0.11 & $1.07(0.45-2.60)$ & 0.86 \\
\hline \multicolumn{7}{|l|}{ Female } \\
\hline TT & Ref & & Ref & & Ref & \\
\hline CT & $0.82(0.53-1.27)$ & 0.38 & $0.95(0.53-1.69)$ & 0.85 & $1.21(0.64-1.94)$ & 0.68 \\
\hline $\mathrm{CC}$ & $0.83(0.47-1.47)$ & 0.52 & $0.81(0.38-1.72)$ & 0.59 & $0.99(0.44-2.05)$ & 0.97 \\
\hline Never smoking & Adjusted $\mathrm{OR}^{\mathfrak{g}}$ & & Adjusted OR & & Adjusted OR & \\
\hline TT & Ref & & Ref & & Ref & \\
\hline CT & $0.91(0.61-1.38)$ & 0.68 & $1.04(0.59-1.86)$ & 0.87 & $1.16(0.66-2.01)$ & 0.59 \\
\hline $\mathrm{CC}$ & $0.97(0.57-1.70)$ & 0.96 & $1.20(0.57-2.50)$ & 0.61 & $1.11(0.55-2.23)$ & 0.31 \\
\hline \multicolumn{7}{|l|}{ Ever smoking } \\
\hline $\mathrm{TT}$ & Ref & & Ref & & Ref & \\
\hline $\mathrm{CT}$ & $1.07(0.55-2.09)$ & 0.83 & $0.86(0.36-2.08)$ & 0.73 & $1.01(0.48-2.11)$ & 0.97 \\
\hline $\mathrm{CC}$ & $0.79(0.32-1.89)$ & 0.59 & $0.93(0.30-2.87)$ & 0.91 & $0.86(0.33-2.22)$ & 0.18 \\
\hline \multicolumn{7}{|l|}{$r s 688$} \\
\hline All patients ${ }^{\dagger}$ & Adjusted $\mathrm{OR}^{\dagger}$ & & Adjusted $\mathrm{OR}^{\dagger}$ & & Adjusted $\mathrm{OR}^{\dagger}$ & \\
\hline $\mathrm{CC}$ & Ref & & Ref & & Ref & \\
\hline CT & $0.91(0.65-1.29)$ & 0.60 & $0.83(0.52-1.35)$ & 0.47 & $0.96(0.62-1.49)$ & 0.87 \\
\hline $\mathrm{TT}$ & $0.88(0.55-1.42)$ & 0.61 & $0.97(0.52-1.82)$ & 0.93 & $0.90(0.50-1.62)$ & 0.74 \\
\hline \multicolumn{7}{|l|}{$X^{2}$} \\
\hline Genotype & 0.141 & & 0.662 & & 0.280 & \\
\hline Allele & 0.070 & & 0.116 & & 0.014 & \\
\hline Male $^{\ddagger}$ & Adjusted $\mathrm{OR}^{\ddagger}$ & & Adjusted $\mathrm{OR}^{\ddagger}$ & & Adjusted $\mathrm{OR}^{\ddagger}$ & \\
\hline $\mathrm{CC}$ & Ref & & Ref & & Ref & \\
\hline $\mathrm{CT}$ & $1.30(0.73-2.33)$ & 0.37 & $1.15(0.49-2.65)$ & 0.75 & $0.99(0.50-1.98)$ & 0.99 \\
\hline $\mathrm{TT}$ & $0.99(0.45-2.21)$ & 0.99 & $1.47(0.47-4.56)$ & 0.50 & $0.81(0.32-2.05)$ & 0.67 \\
\hline \multicolumn{7}{|l|}{ Female $^{\ddagger}$} \\
\hline $\mathrm{CC}$ & Ref & & Ref & & Ref & \\
\hline $\mathrm{CT}$ & $0.76(0.49-1.16)$ & 0.48 & $0.73(0.40-1.32)$ & 0.32 & $0.94(0.54-1.65)$ & 0.84 \\
\hline TT & $0.83(0.46-1.50)$ & 0.55 & $0.83(0.39-1.80)$ & 0.65 & $0.98(0.46-2.08)$ & 0.96 \\
\hline Never smoking & Adjusted $\mathrm{OR}^{\mathrm{g}}$ & & Adjusted $\mathrm{OR}^{9}$ & & Adjusted OR & \\
\hline $\mathrm{CC}$ & Ref & & Ref & & Ref & \\
\hline CT & $0.90(0.60-1.36)$ & 0.63 & $0.84(0.47-1.50)$ & 0.55 & $0.91(0.52-1.58)$ & 0.73 \\
\hline $\mathrm{TT}$ & $0.95(0.54-1.65)$ & 0.54 & $1.06(0.50-2.32)$ & 0.87 & $0.99(0.46-2.04)$ & 0.99 \\
\hline
\end{tabular}


TABle 3: Continued.

\begin{tabular}{|c|c|c|c|c|c|c|}
\hline \multirow{2}{*}{$\begin{array}{l}\text { Gene } \\
\text { SNP } \\
\text { LDLR }\end{array}$} & \multicolumn{2}{|c|}{ Healthy versus periodontitis } & \multicolumn{2}{|c|}{ Healthy versus $\mathrm{T} 2 \mathrm{DM}+\mathrm{P}$} & \multicolumn{2}{|c|}{ Periodontitis versus $\mathrm{T} 2 \mathrm{DM}+\mathrm{P}$} \\
\hline & Adj OR (95\% CI) & $p$ value & Adj OR $(95 \%$ CI $)$ & $p$ value & Adj OR $(95 \%$ CI $)$ & $p$ value \\
\hline \multicolumn{7}{|c|}{ Ever smokings } \\
\hline $\mathrm{CC}$ & Ref & & Ref & & Ref & \\
\hline $\mathrm{CT}$ & $0.92(0.48-1.77)$ & 0.80 & $0.76(0.32-1.81)$ & 0.53 & $0.95(0.46-1.97)$ & 0.90 \\
\hline TT & $0.73(0.29-1.81)$ & 0.50 & $0.78(0.24-2.51)$ & 0.67 & $0.73(0.27-1.99)$ & 0.54 \\
\hline
\end{tabular}

(b)

\begin{tabular}{|c|c|c|c|c|c|c|}
\hline$A P O B$ & Adj OR (95\% CI) & $p$ value & Adj OR (95\% CI) & $p$ value & Adj OR (95\% CI) & $p$ value \\
\hline \multicolumn{7}{|l|}{ rs676210 } \\
\hline All patients ${ }^{\dagger}$ & Adjusted $\mathrm{OR}^{\dagger}$ & & Adjusted OR $\dagger$ & & Adjusted $\mathrm{OR}^{\dagger}$ & \\
\hline GG & Ref & & Ref & & Ref & \\
\hline $\mathrm{AG}$ & $1.30(0.91-1.84)$ & 0.15 & $1.49(0.93-2.37)$ & 0.09 & $1.10(0.72-1.67)$ & 0.65 \\
\hline AA & $1.10(0.38-2.19)$ & 0.78 & $0.43(0.13-1.41)$ & 0.16 & $0.43(0.16-1.15)$ & 0.09 \\
\hline \multicolumn{7}{|l|}{$X^{2}$} \\
\hline Genotype & 1.867 & & 2.435 & & 1.873 & \\
\hline Allele & 1.926 & & 0.262 & & 0.438 & \\
\hline Male $^{\ddagger}$ & Adjusted $\mathrm{OR}^{*}$ & & Adjusted $\mathrm{OR}^{\ddagger}$ & & Adjusted $\mathrm{OR}^{\ddagger}$ & \\
\hline GG & Ref & & Ref & & Ref & \\
\hline AG & $1.10(0.61-2.01)$ & 0.74 & $1.23(0.54-2.79)$ & 0.62 & $1.26(0.64-2.46)$ & 0.49 \\
\hline $\mathrm{AA}$ & $1.59(0.58-4.38)$ & 0.36 & $0.59(0.10-3.44)$ & 0.56 & $0.54(0.15-1.90)$ & 0.33 \\
\hline \multicolumn{7}{|l|}{ Female $^{\ddagger}$} \\
\hline GG & Ref & & Ref & & Ref & \\
\hline AG & $1.43(0.92-2.21)$ & 0.11 & $0.63(0.92-2.87)$ & 0.09 & $0.99(0.58-1.69)$ & 0.99 \\
\hline AA & $0.75(0.28-2.02)$ & 0.57 & $0.28(0.05-1.66)$ & 0.16 & $0.30(0.05-1.63)$ & 0.16 \\
\hline \multirow{2}{*}{ Never smoking } & Adjusted OR & & Adjusted $\mathrm{OR}^{\mathbf{9}}$ & & Adjusted OR & \\
\hline & Ref & & Ref & & Ref & \\
\hline AG & $1.36(0.90-2.04)$ & 0.14 & $1.85(1.06-3.20)$ & 0.03 & $1.13(0.68-1.89)$ & 0.63 \\
\hline AA & $0.81(0.36-1.83)$ & 0.61 & $0.46(0.11-1.86)$ & 0.27 & $0.59(0.15-2.32)$ & 0.45 \\
\hline \multicolumn{7}{|l|}{ Ever smoking } \\
\hline GG & Ref & & Ref & & Ref & \\
\hline AG & $1.15(0.58-2.28)$ & 0.68 & $0.80(0.33-1.94)$ & 0.62 & $1.03(0.49-2.15)$ & 0.94 \\
\hline AA & $2.93(0.59-14.49)$ & 0.19 & $0.23(0.02-2.58)$ & 0.23 & $0.20(0.04-0.96)$ & 0.04 \\
\hline \multicolumn{7}{|l|}{ rs 1042031} \\
\hline All patients ${ }^{\dagger}$ & Adjusted $\mathrm{OR}^{\dagger}$ & & Adjusted $\mathrm{OR}^{\dagger}$ & & Adjusted $\mathrm{OR}^{\dagger}$ & \\
\hline $\mathrm{CC}$ & Ref & & Ref & & Ref & \\
\hline CT & $0.73(0.52-1.03)$ & 0.06 & $0.47(0.28-0.77)$ & $0.003^{*}$ & $0.75(0.47-1.18)$ & 0.21 \\
\hline TT & $0.65(0.23-1.85)$ & 0.42 & $1.38(0.46-4.12)$ & 0.57 & $2.40(0.79-7.21)$ & 0.12 \\
\hline \multicolumn{7}{|l|}{$X^{2}$} \\
\hline Genotype & 3.187 & & 9.236 & & 4.663 & \\
\hline Allele & 2.875 & & 3.167 & & 0.158 & \\
\hline Male & Adjusted $\mathrm{OR}^{\ddagger}$ & & Adjusted $\mathrm{OR}^{\ddagger}$ & & Adjusted $\mathrm{OR}^{\ddagger}$ & \\
\hline $\mathrm{CC}$ & Ref & & Ref & & Ref & \\
\hline CT & $0.92(0.51-1.64)$ & 0.78 & $0.78(0.33-1.82)$ & 0.56 & $0.96(0.47-1.92)$ & 0.90 \\
\hline TT & $0.34(0.06-2.08)$ & 0.24 & $0.92(0.12-6.72)$ & 0.93 & $2.56(0.32-19.92)$ & 0.36 \\
\hline
\end{tabular}


TABle 3: Continued.

\begin{tabular}{|c|c|c|c|c|c|c|}
\hline$A P O B$ & Adj OR (95\% CI) & $p$ value & Adj OR (95\% CI) & $p$ value & Adj OR (95\% CI) & $p$ value \\
\hline \multicolumn{7}{|l|}{ Female } \\
\hline $\mathrm{CC}$ & Ref & & Ref & & Ref & \\
\hline $\mathrm{CT}$ & $0.64(0.92-2.21)$ & 0.11 & $0.34(0.18-0.65)$ & $0.001^{*}$ & $0.62(0.33-1.13)$ & 0.12 \\
\hline $\mathrm{TT}$ & $0.92(0.25-3.33)$ & 0.89 & $1.74(0.45-6.60)$ & 0.41 & $2.29(0.64-8.30)$ & 0.20 \\
\hline Never smoking & Adjusted $\mathrm{OR}^{\mathfrak{g}}$ & & Adjusted OR & & Adjusted $\mathrm{OR}^{9}$ & \\
\hline $\mathrm{CC}$ & Ref & & Ref & & Ref & \\
\hline $\mathrm{CT}$ & $0.70(0.47-1.06)$ & 0.09 & $0.40(0.21-0.75)$ & 0.004 & $0.77(0.42-1.40)$ & 0.39 \\
\hline $\mathrm{TT}$ & $0.55(0.15-2.01)$ & 0.37 & $1.19(0.29-4.81)$ & 0.80 & $1.96(0.45-8.60)$ & 0.37 \\
\hline \multicolumn{7}{|l|}{ Ever smoking } \\
\hline $\mathrm{CC}$ & Ref & & Ref & & Ref & \\
\hline $\mathrm{CT}$ & $0.78(0.41-1.46)$ & 0.43 & $0.80(0.41-1.46)$ & 0.43 & $0.64(0.30-1.34)$ & 0.64 \\
\hline TT & $0.89(0.14-5.64)$ & 0.90 & $0.89(0.14-5.64)$ & 0.90 & $3.84(0.69-21.39)$ & 0.12 \\
\hline \multicolumn{7}{|c|}{ Female+never smoking ${ }^{¥}$} \\
\hline $\mathrm{CC}$ & Ref & & Ref & & Ref & \\
\hline $\mathrm{CT}$ & $1.13(0.45-2.82)$ & 0.78 & $0.31(0.15-0.69)$ & 0.004 & $0.55(0.25-1.17)$ & 0.12 \\
\hline TT & $0.57(0.03-9.61)$ & 0.69 & $1.93(0.43-8.60)$ & 0.38 & $2.56(0.52-12.49)$ & 0.24 \\
\hline \multicolumn{7}{|l|}{$r s 693$} \\
\hline All patients ${ }^{\dagger}$ & Adjusted $\mathrm{OR}^{\dagger}$ & & Adjusted $\mathrm{OR}^{\dagger}$ & & Adjusted $\mathrm{OR}^{\dagger}$ & \\
\hline GG & Ref & & Ref & & Ref & \\
\hline AG & $1.05(0.74-1.48)$ & 0.77 & $0.98(0.62-1.55)$ & 0.93 & $0.95(0.62-1.43)$ & 0.80 \\
\hline AA & $0.83(0.52-1.33)$ & 0.44 & $0.90(0.48-1.69)$ & 0.75 & $0.82(0.45-1.48)$ & 0.52 \\
\hline \multicolumn{7}{|l|}{$X^{2}$} \\
\hline Genotype & 0.568 & & 0.955 & & 0.137 & \\
\hline Allele & 0.032 & & 0.154 & & 0.057 & \\
\hline Male $^{\ddagger}$ & Adjusted $\mathrm{OR}^{\ddagger}$ & & Adjusted $\mathrm{OR}^{\ddagger}$ & & Adjusted $\mathrm{OR}^{\ddagger}$ & \\
\hline GG & Ref & & Ref & & Ref & \\
\hline $\mathrm{AG}$ & $0.91(0.51-1.64)$ & 0.76 & $0.67(0.29-1.51)$ & 0.33 & $0.75(0.38-1.48)$ & 0.41 \\
\hline AA & $1.02(0.49-2.15)$ & 0.94 & $0.79(0.27-2.29)$ & 0.67 & $0.51(0.21-1.24)$ & 0.14 \\
\hline \multicolumn{7}{|l|}{ Female $^{\ddagger}$} \\
\hline GG & Ref & & Ref & & Ref & \\
\hline AG & $1.43(0.92-2.21)$ & 0.11 & $1.19(0.68-2.09)$ & 0.52 & $1.10(0.64-1.88)$ & 0.71 \\
\hline $\mathrm{AA}$ & $0.76(0.28-2.02)$ & 0.57 & $0.95(0.43-2.11)$ & 0.91 & $1.23(0.55-2.74)$ & 0.60 \\
\hline Never smoking & Adjusted OR & & Adjusted OR & & Adjusted OR & \\
\hline GG & Ref & & Ref & & Ref & \\
\hline AG & $1.22(0.81-1.83)$ & 0.33 & $1.07(0.62-1.86)$ & 0.25 & $1.04(0.61-1.75)$ & 0.88 \\
\hline $\mathrm{AA}$ & $0.77(0.44-1.36)$ & 0.37 & $0.91(0.43-1.96)$ & 0.82 & $1.01(0.48-2.14)$ & 0.97 \\
\hline \multicolumn{7}{|l|}{ Ever smokings } \\
\hline GG & Ref & & Ref & & Ref & \\
\hline AG & $0.72(0.37-1.39)$ & 0.33 & $0.85(0.36-1.96)$ & 0.70 & $0.72(0.35-1.47)$ & 0.37 \\
\hline $\mathrm{AA}$ & $0.91(0.38-2.21)$ & 0.85 & $0.91(0.29-2.83)$ & 0.87 & $0.63(0.24-1.63)$ & 0.34 \\
\hline
\end{tabular}

(c)

\begin{tabular}{|c|c|c|c|c|c|c|}
\hline$A B C C 8$ & Adj OR (95\% CI) & $p$ value & Adj OR (95\% CI) & $p$ value & Adj OR (95\% CI) & $p$ value \\
\hline \multicolumn{7}{|l|}{ rs6544718 } \\
\hline All patients ${ }^{\dagger}$ & Adjusted $\mathrm{OR}^{\dagger}$ & & Adjusted $\mathrm{OR}^{\dagger}$ & & Adjusted $\mathrm{OR}^{\dagger}$ & \\
\hline $\mathrm{CC}$ & Ref & & Ref & & Ref & \\
\hline CT & $0.87(0.60-1.25)$ & 0.45 & $0.71(0.45-1.12)$ & 0.15 & $0.93(0.57-1.52)$ & 0.79 \\
\hline TT & $1.21(0.43-3.39)$ & 0.71 & $0.64(0.15-2.70)$ & 0.54 & $0.42(0.10-1.73)$ & 0.23 \\
\hline
\end{tabular}


TABle 3: Continued.

\begin{tabular}{|c|c|c|c|c|c|c|}
\hline$A B C C 8$ & Adj OR (95\% CI) & $p$ value & Adj OR (95\% CI) & $p$ value & Adj OR (95\% CI) & $p$ value \\
\hline \multicolumn{7}{|l|}{$X^{2}$} \\
\hline Genotype & 1.023 & & NA & & NA & \\
\hline Allele & 0.072 & & 0.901 & & 1.377 & \\
\hline Male $^{\ddagger}$ & Adjusted $\mathrm{OR}^{\ddagger}$ & & Adjusted $\mathrm{OR}^{\ddagger}$ & & Adjusted $\mathrm{OR}^{\ddagger}$ & \\
\hline $\mathrm{CC}$ & Ref & & Ref & & Ref & \\
\hline $\mathrm{CT}$ & $0.75(0.41-1.37)$ & 0.35 & $0.37(0.16-0.83)$ & 0.01 & $0.74(0.29-1.87)$ & 0.52 \\
\hline $\mathrm{TT}$ & $0.75(0.10-5.45)$ & 0.77 & $0.89(0.12-6.19)$ & 0.90 & $1.96(0.16-22.84)$ & 0.59 \\
\hline \multicolumn{7}{|l|}{ Female } \\
\hline $\mathrm{CC}$ & Ref & & Ref & & Ref & \\
\hline $\mathrm{CT}$ & $0.95(0.60-1.50)$ & 0.84 & $1.01(0.57-1.77)$ & 0.96 & $1.06(0.60-1.89)$ & 0.82 \\
\hline $\mathrm{TT}$ & $1.43(0.42-4.76)$ & 0.55 & $0.40(0.04-3.99)$ & 0.44 & $0.17(0.02-1.55)$ & 0.11 \\
\hline Never smokings & Adjusted OR & & Adjusted OR & & Adjusted OR & \\
\hline $\mathrm{CC}$ & Ref & & Ref & & Ref & \\
\hline CT & $0.90(0.59-1.38)$ & 0.65 & $0.69(0.38-1.27)$ & 0.24 & $0.66(0.36-1.20)$ & 0.17 \\
\hline $\mathrm{TT}$ & $0.59(0.14-2.39)$ & 0.46 & $1.36(0.08-22.70)$ & 0.83 & $0.15(0.01-1.35)$ & 0.09 \\
\hline \multicolumn{7}{|l|}{ Ever smoking $^{\dagger}$} \\
\hline $\mathrm{CC}$ & Ref & & Ref & & Ref & \\
\hline $\mathrm{CT}$ & $0.78(0.39-1.54)$ & 0.47 & $0.72(0.36-1.44)$ & 0.35 & $1.88(0.71-4.98)$ & 0.20 \\
\hline $\mathrm{TT}$ & $3.94(0.46-33.82)$ & 0.21 & $0.51(0.89-2.91)$ & 0.45 & $2.46(0.29-20.84)$ & 0.40 \\
\hline \multicolumn{7}{|l|}{ rs6544713 } \\
\hline All patients ${ }^{\dagger}$ & Adjusted $\mathrm{OR}^{\dagger}$ & & Adjusted $\mathrm{OR}^{\dagger}$ & & Adjusted $\mathrm{OR}^{\dagger}$ & \\
\hline $\mathrm{CC}$ & Ref & & Ref & & Ref & \\
\hline $\mathrm{CT}$ & $1.06(0.76-1.49)$ & 0.69 & $0.93(0.61-1.41)$ & 0.74 & $1.04(0.66-1.62)$ & 0.86 \\
\hline TT & $1.10(0.61-1.98)$ & 0.74 & $1.30(0.63-2.67)$ & 0.46 & $1.21(0.59-2.4)$ & 0.59 \\
\hline \multicolumn{7}{|l|}{$X^{2}$} \\
\hline Genotype & 0.379 & & 0.491 & & 0.081 & \\
\hline Allele & 0.384 & & 0.504 & & 0.032 & \\
\hline Male & Adjusted $\mathrm{OR}^{\neq}$ & & Adjusted $\mathrm{OR}^{\ddagger}$ & & Adjusted $\mathrm{OR}^{\ddagger}$ & \\
\hline $\mathrm{CC}$ & Ref & & Ref & & Ref & \\
\hline $\mathrm{CT}$ & $1.04(0.59-1.81)$ & 0.84 & $0.75(0.39-1.45)$ & 0.40 & $0.73(0.34-1.56)$ & 0.42 \\
\hline $\mathrm{TT}$ & $0.67(0.22-2.03)$ & 0.48 & $0.61(0.16-2.30)$ & 0.47 & $1.32(0.29-6.06)$ & 0.71 \\
\hline \multicolumn{7}{|l|}{ Female $^{\ddagger}$} \\
\hline $\mathrm{CC}$ & Ref & & Ref & & Ref & \\
\hline $\mathrm{CT}$ & $1.06(0.69-1.62)$ & 0.78 & $1.07(0.62-1.83)$ & 0.80 & $1.25(0.71-2.18)$ & 0.42 \\
\hline $\mathrm{TT}$ & $1.34(0.66-2.71)$ & 0.40 & $1.90(0.79-4.57)$ & 0.15 & $1.23(0.55-2.74)$ & 0.59 \\
\hline Never smoking & Adjusted $\mathrm{OR}^{9}$ & & Adjusted $\mathrm{OR}^{9}$ & & Adjusted OR & \\
\hline $\mathrm{CC}$ & Ref & & Ref & & Ref & \\
\hline $\mathrm{CT}$ & $0.89(0.60-1.33)$ & 0.58 & $0.88(0.51-1.50)$ & 0.64 & $0.84(0.49-1.44)$ & 0.54 \\
\hline $\mathrm{TT}$ & $1.02(0.51-2.02)$ & 0.94 & $1.46(0.57-3.71)$ & 0.41 & $0.86(0.36-2.04)$ & 0.73 \\
\hline \multicolumn{7}{|l|}{ Ever smoking $^{\dagger}$} \\
\hline $\mathrm{CC}$ & Ref & & Ref & & Ref & \\
\hline $\mathrm{CT}$ & $1.70(0.88-3.26)$ & 0.10 & $1.00(0.51-1.94)$ & 0.99 & $1.52(0.66-3.53)$ & 0.32 \\
\hline TT & $1.29(0.39-4.20)$ & 0.67 & $1.06(0.34-3.27)$ & 0.91 & $2.84(0.73-10.95)$ & 0.12 \\
\hline
\end{tabular}


(d)

\begin{tabular}{|c|c|c|c|c|c|c|}
\hline$\overline{L P L}$ & Adj OR $(95 \%$ CI $)$ & $p$ value & Adj OR (95\% CI) & $p$ value & Adj OR (95\% CI) & $p$ value \\
\hline \multicolumn{7}{|l|}{$r s 285$} \\
\hline All patients ${ }^{\dagger}$ & Adjusted OR $\dagger$ & & Adjusted $\mathrm{OR}^{\dagger}$ & & Adjusted $\mathrm{OR}^{\dagger}$ & \\
\hline $\mathrm{TT}$ & Ref & & Ref & & Ref & \\
\hline CT & $0.87(0.60-1.26)$ & 0.48 & $0.71(0.44-1.14)$ & 0.16 & $0.88(0.53-1.43)$ & 0.61 \\
\hline $\mathrm{CC}$ & $0.71(0.46-1.11)$ & 0.13 & $0.86(0.50-1.46)$ & 0.58 & $0.95(0.55-1.66)$ & 0.88 \\
\hline \multicolumn{7}{|l|}{$X^{2}$} \\
\hline Genotype & 1.566 & & 1.76 & & 1.166 & \\
\hline Allele & 1.445 & & 0.144 & & 0.399 & \\
\hline $\mathrm{Male}^{\ddagger}$ & Adjusted $\mathrm{OR}^{\ddagger}$ & & Adjusted $\mathrm{OR}^{\ddagger}$ & & Adjusted $\mathrm{OR}^{\ddagger}$ & \\
\hline $\mathrm{TT}$ & Ref & & Ref & & Ref & \\
\hline CT & $0.44(0.23-0.85)$ & 0.01 & $0.62(0.29-1.33)$ & 0.22 & $0.91(0.39-2.11)$ & 0.83 \\
\hline $\mathrm{CC}$ & $0.64(0.29-1.37)$ & 0.25 & $0.49(0.20-1.22)$ & 0.13 & $0.71(0.26-1.93)$ & 0.51 \\
\hline \multicolumn{7}{|l|}{ Female } \\
\hline TT & Ref & & Ref & & Ref & \\
\hline CT & $1.22(0.76-1.94)$ & 0.39 & $0.76(0.41-1.39)$ & 0.38 & $0.83(0.45-1.54)$ & 0.45 \\
\hline $\mathrm{CC}$ & $0.74(0.43-1.29)$ & 0.29 & $1.17(0.60-2.29)$ & 0.62 & $1.06(0.54-2.08)$ & 0.85 \\
\hline Never smokings & Adjusted OR & & Adjusted OR & & Adjusted OR & \\
\hline TT & Ref & & Ref & & Ref & \\
\hline $\mathrm{CT}$ & $0.94(0.60-1.46)$ & 0.78 & $0.79(0.38-1.30)$ & 0.26 & $0.95(0.52-1.74)$ & 0.88 \\
\hline $\mathrm{CC}$ & $0.90(0.53-1.50)$ & 0.69 & $0.93(0.48-1.79)$ & 0.83 & $1.16(0.60-2.21)$ & 0.64 \\
\hline \multicolumn{7}{|l|}{ Ever smoking ${ }^{\dagger}$} \\
\hline TT & Ref & & Ref & & Ref & \\
\hline CT & $0.70(0.34-1.44)$ & 0.34 & $0.69(0.33-1.47)$ & 0.34 & $0.53(0.20-1.39)$ & 0.20 \\
\hline $\mathrm{CC}$ & $0.38(0.16-0.89)$ & 0.02 & $0.75(0.29-1.93)$ & 0.55 & $1.04(0.18-1.78)$ & 0.33 \\
\hline \multicolumn{7}{|l|}{$r s 3735964$} \\
\hline All patients ${ }^{\dagger}$ & Adjusted $\mathrm{OR}^{\dagger}$ & & Adjusted $\mathrm{OR}^{\dagger}$ & & Adjusted $\mathrm{OR}^{\dagger}$ & \\
\hline $\mathrm{CC}$ & Ref & & Ref & & Ref & \\
\hline $\mathrm{AC}$ & $0.76(0.50-1.14)$ & 0.19 & $1.12(0.67-1.86)$ & 0.64 & $1.10(0.62-1.87)$ & 0.70 \\
\hline $\mathrm{AA}$ & $0.77(0.21-2.82)$ & 0.69 & 1 & - & 1 & - \\
\hline \multicolumn{7}{|l|}{$X^{2}$} \\
\hline Genotype & NA & & NA & & NA & \\
\hline Allele & 1.738 & & 0.767 & & 0.045 & \\
\hline $\mathrm{Male}^{\ddagger}$ & Adjusted $\mathrm{OR}^{*}$ & & Adjusted $\mathrm{OR}^{\ddagger}$ & & Adjusted $\mathrm{OR}^{\ddagger}$ & \\
\hline $\mathrm{CC}$ & Ref & & Ref & & Ref & \\
\hline $\mathrm{AC}$ & $0.62(0.31-1.24)$ & 0.18 & $1.95(0.88-2.40)$ & 0.09 & $1.15(0.49-2.68)$ & 0.74 \\
\hline $\mathrm{AA}$ & 1 & - & - & - & 1 & - \\
\hline \multicolumn{7}{|l|}{ Female } \\
\hline $\mathrm{CC}$ & Ref & & Ref & & Ref & \\
\hline $\mathrm{AC}$ & $0.83(0.50-1.39)$ & 0.48 & $1.07(0.62-1.83)$ & 0.80 & $1.02(0.51-2.06)$ & 0.93 \\
\hline $\mathrm{AA}$ & $0.62(0.15-2.57)$ & 0.51 & $1.90(0.79-4.57)$ & 0.15 & 1 & - \\
\hline Never smokings & Adjusted OR & & Adjusted OR & & Adjusted $\mathrm{OR}^{9}$ & \\
\hline $\mathrm{CC}$ & Ref & & Ref & & Ref & \\
\hline $\mathrm{AC}$ & $0.69(0.42-1.14)$ & 0.15 & $1.77(0.94-3.33)$ & 0.07 & $1.29(0.71-2.35)$ & 0.39 \\
\hline $\mathrm{AA}$ & $0.60(0.14-2.48)$ & 0.48 & 1 & - & 1 & - \\
\hline \multicolumn{7}{|l|}{ Ever smoking ${ }^{\dagger g}$} \\
\hline $\mathrm{CC}$ & Ref & & Ref & & Ref & \\
\hline $\mathrm{AC}$ & $0.93(0.44-1.96)$ & 0.84 & $0.52(0.21-1.27)$ & 0.15 & $0.60(0.19-1.89)$ & 0.38 \\
\hline AA & 1 & - & - & - & 1 & - \\
\hline
\end{tabular}


TABle 3: Continued.

\begin{tabular}{|c|c|c|c|c|c|c|}
\hline$L P L$ & Adj OR $(95 \%$ CI $)$ & $p$ value & Adj OR (95\% CI) & $p$ value & Adj OR (95\% CI) & $p$ value \\
\hline \multicolumn{7}{|l|}{$r s 13702$} \\
\hline All patients ${ }^{\dagger}$ & Adjusted $\mathrm{OR}^{\dagger}$ & & Adjusted $\mathrm{OR}^{\dagger}$ & & Adjusted $\mathrm{OR}^{\dagger}$ & \\
\hline $\mathrm{TT}$ & Ref & & Ref & & Ref & \\
\hline $\mathrm{CT}$ & $0.88(0.62-1.25)$ & 0.49 & $0.97(0.62-1.52)$ & 0.98 & $0.74(0.46-1.20)$ & 0.23 \\
\hline $\mathrm{CC}$ & $1.07(0.62-1.83)$ & 0.80 & $1.20(0.62-2.34)$ & 0.57 & $1.44(0.70-2.98)$ & 0.31 \\
\hline \multicolumn{7}{|l|}{$X^{2}$} \\
\hline Genotype & 0.695 & & 2.215 & & 1.092 & \\
\hline Allele & 0.581 & & 0.547 & & 0.011 & \\
\hline Male $^{\ddagger}$ & Adjusted $\mathrm{OR}^{\ddagger}$ & & Adjusted $\mathrm{OR}^{\ddagger}$ & & Adjusted $\mathrm{OR}^{\ddagger}$ & \\
\hline $\mathrm{TT}$ & Ref & & Ref & & Ref & \\
\hline CT & $0.77(0.42-1.39)$ & 0.39 & $1.92(0.92-3.99)$ & 0.08 & $0.86(0.36-2.04)$ & 0.73 \\
\hline $\mathrm{CC}$ & $1.26(0.51-3.11)$ & 0.61 & $4.38(1.52-12.58)$ & 0.006 & $2.17(0.69-6.81)$ & 0.18 \\
\hline \multicolumn{7}{|l|}{ Female $^{\ddagger}$} \\
\hline $\mathrm{TT}$ & Ref & & Ref & & Ref & \\
\hline $\mathrm{CT}$ & $0.94(0.60-1.46)$ & 0.79 & $0.64(0.36-1.13)$ & 0.68 & $0.68(0.38-1.20)$ & 0.18 \\
\hline $\mathrm{CC}$ & $0.98(0.50-1.93)$ & 0.96 & $0.47(0.18-1.20)$ & 0.11 & $1.10(0.40-2.97)$ & 0.85 \\
\hline Never smoking & Adjusted $\mathrm{OR}^{9}$ & & Adjusted OR & & Adjusted $\mathrm{OR}^{9}$ & \\
\hline $\mathrm{TT}$ & Ref & & Ref & & Ref & \\
\hline $\mathrm{CT}$ & $0.74(0.49-1.12)$ & 0.16 & $0.98(0.56-1.73)$ & 0.95 & $0.81(0.46-1.42)$ & 0.47 \\
\hline $\mathrm{CC}$ & $0.79(0.43-1.46)$ & 0.46 & $0.74(0.30-1.85)$ & 0.53 & $0.92(0.37-2.26)$ & 0.86 \\
\hline \multicolumn{7}{|l|}{ Ever smoking ${ }^{\dagger}$} \\
\hline $\mathrm{TT}$ & Ref & & Ref & & Ref & \\
\hline $\mathrm{CT}$ & $1.35(0.70-2.59)$ & 0.36 & $1.02(0.49-2.11)$ & 0.94 & $0.56(0.23-1.39)$ & 0.21 \\
\hline
\end{tabular}

(e)

\begin{tabular}{|c|c|c|c|c|c|c|}
\hline HNF1A & Adj OR (95\% CI) & $p$ value & Adj OR (95\% CI) & $p$ value & Adj OR (95\% CI) & $p$ value \\
\hline \multicolumn{7}{|l|}{$r s 2650000$} \\
\hline All patients ${ }^{\dagger}$ & Adjusted $\mathrm{OR}^{\dagger}$ & & Adjusted $\mathrm{OR}^{\dagger}$ & & Adjusted $\mathrm{OR}^{\dagger}$ & \\
\hline $\mathrm{CC}$ & Ref & & Ref & & Ref & \\
\hline $\mathrm{AC}$ & $0.82(0.59-1.15)$ & 0.26 & $1.18(0.78-1.79)$ & 0.42 & $0.80(0.51-1.24)$ & 0.32 \\
\hline $\mathrm{AA}$ & $0.87(0.49-1.52)$ & 0.63 & $0.96(0.49-1.85)$ & 0.90 & $1.14(0.56-2.35)$ & 0.70 \\
\hline \multicolumn{7}{|l|}{$X^{2}$} \\
\hline Genotype & 1.098 & & 1.071 & & 0.021 & \\
\hline Allele & 0.181 & & 0.193 & & 0.006 & \\
\hline Male $^{\ddagger}$ & Adjusted $\mathrm{OR}^{\ddagger}$ & & Adjusted $\mathrm{OR}^{\ddagger}$ & & Adjusted $\mathrm{OR}^{\ddagger}$ & \\
\hline $\mathrm{CC}$ & Ref & & Ref & & Ref & \\
\hline $\mathrm{AC}$ & $1.10(0.62-1.94)$ & 0.72 & $1.68(0.85-3.32)$ & 0.13 & $0.96(0.45-2.04)$ & 0.91 \\
\hline $\mathrm{AA}$ & $1.76(0.67-4.58)$ & 0.24 & $0.55(0.18-1.62)$ & 0.28 & $0.71(0.19-2.65)$ & 0.61 \\
\hline \multicolumn{7}{|l|}{ Female $^{\ddagger}$} \\
\hline $\mathrm{CC}$ & Ref & & Ref & & Ref & \\
\hline $\mathrm{AC}$ & $0.71(0.47-1.08)$ & 0.11 & $0.95(0.55-1.61)$ & 0.85 & $0.71(0.41-1.22)$ & 0.22 \\
\hline $\mathrm{AA}$ & $0.56(0.27-1.16)$ & 0.12 & $1.43(0.61-3.33)$ & 0.40 & $1.33(0.57-3.10)$ & 0.50 \\
\hline Never smoking & Adjusted $\mathrm{OR}^{\mathfrak{g}}$ & & Adjusted OR & & Adjusted OR & \\
\hline $\mathrm{CC}$ & Ref & & Ref & & Ref & \\
\hline $\mathrm{AC}$ & $0.68(0.46-1.01)$ & 0.61 & $1.56(0.91-2.68)$ & 0.10 & $1.00(0.58-1.69)$ & 0.99 \\
\hline AA & $0.96(0.49-1.86)$ & 0.90 & $1.38(0.62-3.07)$ & 0.42 & $1.70(0.73-3.94)$ & 0.21 \\
\hline
\end{tabular}


TABle 3: Continued.

\begin{tabular}{lcccccc}
\hline HNF1A & Adj OR (95\% CI) & $p$ value & Adj OR (95\% CI) & $p$ value & Adj OR (95\% CI) & $p$ value \\
\hline Ever smoking & & & & & \\
CC & Ref & & Ref & & Ref \\
AC & $1.34(0.70-2.57)$ & 0.36 & $0.80(0.41-1.57)$ & 0.53 & $0.60(0.26-1.37)$ \\
AA & $0.73(0.26-2.03)$ & 0.55 & $0.48(0.14-1.61)$ & 0.24 & $0.58(0.15-2.25)$ & 0.43 \\
\hline
\end{tabular}

(f)

\begin{tabular}{|c|c|c|c|c|c|c|}
\hline$A P O E$ & Adj OR $(95 \%$ CI $)$ & $p$ value & Adj OR $(95 \% \mathrm{CI})$ & $p$ value & Adj OR (95\% CI) & $p$ value \\
\hline \multicolumn{7}{|l|}{$r s 429358$} \\
\hline All patients ${ }^{\dagger}$ & Adjusted $\mathrm{OR}^{\dagger}$ & & Adjusted $\mathrm{OR}^{\dagger}$ & & Adjusted $\mathrm{OR}^{\dagger}$ & \\
\hline $\mathrm{TT}$ & Ref & & Ref & & Ref & \\
\hline $\mathrm{CT}$ & $1.06(0.73-1.54)$ & 0.73 & $0.84(0.52-1.36)$ & 0.48 & $0.84(0.45-1.12)$ & 0.15 \\
\hline $\mathrm{CC}$ & $1.79(0.63-5.05)$ & 0.27 & $0.43(0.11-1.64)$ & 0.21 & $0.64(0.15-2.7)$ & 0.54 \\
\hline \multicolumn{7}{|l|}{$X^{2}$} \\
\hline Genotype & 1.032 & & NA & & NA & \\
\hline Allele & 0.611 & & 0.399 & & 1.649 & \\
\hline Male $^{\neq}$ & Adjusted $\mathrm{OR}^{\ddagger}$ & & Adjusted $\mathrm{OR}^{\ddagger}$ & & Adjusted $\mathrm{OR}^{\ddagger}$ & \\
\hline TT & Ref & & Ref & & Ref & \\
\hline $\mathrm{CT}$ & $1.22(0.64-2.33)$ & 0.54 & $0.73(0.34-1.53)$ & 0.41 & $0.86(0.36-2.05)$ & 0.73 \\
\hline $\mathrm{CC}$ & $4.76(0.56-40.48)$ & 0.15 & 1 & - & 1 & - \\
\hline \multicolumn{7}{|l|}{ Female $^{\ddagger}$} \\
\hline $\mathrm{TT}$ & Ref & & Ref & & Ref & \\
\hline $\mathrm{CT}$ & $0.98(0.62-1.56)$ & 0.96 & $0.91(0.48-1.72)$ & 0.79 & $0.69(0.36-1.31)$ & 0.26 \\
\hline $\mathrm{CC}$ & $1.06(0.28-3.95)$ & 0.92 & $0.78(0.18-3.36)$ & 0.74 & $2.28(0.31-16.53)$ & 0.41 \\
\hline Never smoking' & Adjusted OR & & Adjusted OR & & Adjusted OR & \\
\hline $\mathrm{TT}$ & Ref & & Ref & & Ref & \\
\hline CT & $1.15(0.74-1.79)$ & 0.52 & $0.86(0.47-1.60)$ & 0.65 & $0.87(0.47-1.61)$ & 0.67 \\
\hline $\mathrm{CC}$ & $0.93(0.28-5.36)$ & 0.77 & $0.60(0.11-3.31)$ & 0.56 & $5.04(0.39-63.54)$ & 0.21 \\
\hline \multicolumn{7}{|l|}{ Ever smoking } \\
\hline $\mathrm{TT}$ & Ref & & Ref & & Ref & \\
\hline $\mathrm{CT}$ & $0.88(0.43-1.77)$ & 0.72 & $0.76(0.34-1.66)$ & 0.49 & $0.40(0.14-1.09)$ & 0.07 \\
\hline $\mathrm{TT}$ & 1 & - & 1 & - & $8.56(0.42-174.7)$ & 0.16 \\
\hline \multicolumn{7}{|l|}{$r s 7412$} \\
\hline \multicolumn{7}{|l|}{ All patients } \\
\hline $\mathrm{CC}$ & Ref & & Ref & & & \\
\hline $\mathrm{CT}$ & $0.91(0.55-1.50)$ & 0.72 & $1.15(0.63-2.08)$ & 0.64 & $1.30(0.69-2.46)$ & 0.41 \\
\hline $\mathrm{TT}$ & 1 & - & 1 & - & $3.41(0.50-23.19)$ & 0.20 \\
\hline \multicolumn{7}{|l|}{$X^{2}$} \\
\hline Genotype & NA & & NA & & NA & \\
\hline Allele & 1.831 & & 0.4281 & & 3.407 & \\
\hline Male $^{\ddagger}$ & Adjusted $\mathrm{OR}^{\ddagger}$ & & Adjusted $\mathrm{OR}^{\ddagger}$ & & Adjusted $\mathrm{OR}^{\ddagger}$ & \\
\hline $\mathrm{CC}$ & Ref & & Ref & & Ref & \\
\hline $\mathrm{CT}$ & $1.13(0.45-2.82)$ & 0.78 & $1.87(0.71-4.92$ & 0.20 & $2.92(0.88-9.63)$ & 0.07 \\
\hline $\mathrm{TT}$ & 1 & - & 1 & - & $1.29(0.01-142.0)$ & 0.91 \\
\hline \multicolumn{7}{|l|}{ Female $^{\ddagger}$} \\
\hline $\mathrm{CC}$ & Ref & & Ref & & Ref & \\
\hline $\mathrm{CT}$ & $0.83(0.45-1.52)$ & 0.56 & $0.84(0.39-1.84)$ & 0.68 & $0.92(0.41-2.03)$ & 0.83 \\
\hline $\mathrm{TT}$ & 1 & - & 1 & - & $4.03(0.46-34.93)$ & 0.20 \\
\hline
\end{tabular}


TABLE 3: Continued.

\begin{tabular}{|c|c|c|c|c|c|c|}
\hline$\overline{A P O E}$ & Adj OR $(95 \%$ CI $)$ & $p$ value & Adj OR (95\% CI) & $p$ value & Adj OR (95\% CI) & $p$ value \\
\hline Never smokings & Adjusted $\mathrm{OR}^{9}$ & & Adjusted $\mathrm{OR}^{9}$ & & Adjusted $\mathrm{OR}^{9}$ & \\
\hline $\mathrm{CC}$ & Ref & & Ref & & Ref & \\
\hline CT & $0.97(0.53-1.76)$ & 0.93 & $1.40(0.69-2.83)$ & 0.34 & $1.64(0.79-3.40)$ & 0.17 \\
\hline TT & 1 & - & 1 & - & $2.35(0.16-33.59)$ & 0.52 \\
\hline \multicolumn{7}{|l|}{ Ever smoking $^{\dagger}$} \\
\hline $\mathrm{CC}$ & Ref & & Ref & & Ref & \\
\hline CT & $0.77(0.30-1.95)$ & 0.58 & $0.71(0.23-2.17)$ & 0.55 & $0.83(.020-3.33)$ & 0.79 \\
\hline TT & 1 & - & 1 & - & $8.56(0.42-174.7)$ & 0.16 \\
\hline
\end{tabular}

(g)

\begin{tabular}{|c|c|c|c|c|c|c|}
\hline HNF4A & Adj OR (95\% CI) & $p$ value & Adj OR (95\% CI) & $p$ value & Adj OR (95\% CI) & $p$ value \\
\hline \multicolumn{7}{|l|}{$r s 1800961$} \\
\hline All patients ${ }^{\dagger}$ & Adjusted $\mathrm{OR}^{\dagger}$ & & Adjusted $\mathrm{OR}^{\dagger}$ & & Adjusted $\mathrm{OR}^{\dagger}$ & \\
\hline $\mathrm{CC}$ & Ref & & Ref & & Ref & \\
\hline $\mathrm{CT}$ & $0.90(0.45-1.82)$ & 0.78 & $1.96(1.01-3.80)$ & 0.04 & $3.75(1.64-8.60)$ & $0.002^{*}$ \\
\hline TT & 1 & - & 1 & - & 1 & - \\
\hline \multicolumn{7}{|l|}{$X^{2}$} \\
\hline Genotype & NA & & NA & & NA & \\
\hline Allele & 0.114 & & 4.592 & & 6 & \\
\hline Male $^{\ddagger}$ & Adjusted $\mathrm{OR}^{\ddagger}$ & & Adjusted $\mathrm{OR}^{\ddagger}$ & & Adjusted $\mathrm{OR}^{\ddagger}$ & \\
\hline $\mathrm{CC}$ & Ref & & Ref & & Ref & \\
\hline $\mathrm{CT}$ & $1.50(0.46-4.92)$ & 0.49 & $1.48(0.52-4.21)$ & 0.45 & $6.08(1.25-29.48)$ & 0.02 \\
\hline $\mathrm{TT}$ & - & - & - & - & - & - \\
\hline \multicolumn{7}{|l|}{ Female } \\
\hline $\mathrm{CC}$ & Ref & & Ref & & Ref & \\
\hline CT & $0.67(0.27-1.66)$ & 0.39 & $2.36(1.01-5.56)$ & 0.04 & $3.23(1.22-8.58)$ & 0.01 \\
\hline $\mathrm{TT}$ & 1 & - & 1 & - & 1 & - \\
\hline Never smokings & Adjusted $\mathrm{OR}^{9}$ & & Adjusted $\mathrm{OR}^{9}$ & & Adjusted $\mathrm{OR}^{5}$ & \\
\hline $\mathrm{CC}$ & Ref & & Ref & & Ref & \\
\hline $\mathrm{CT}$ & $0.97(0.43-2.19)$ & 0.95 & $1.84(0.77-4.35)$ & 0.16 & $2.96(1.16-7.53)$ & 0.02 \\
\hline $\mathrm{TT}$ & 1 & - & - & - & 1 & - \\
\hline \multicolumn{7}{|l|}{ Ever smoking ${ }^{\dagger}$} \\
\hline $\mathrm{CC}$ & Ref & & Ref & & Ref & \\
\hline $\mathrm{CT}$ & $0.72(0.18-2.83)$ & 0.64 & $2.14(0.76-6.01)$ & 0.14 & $6.23(0.74-52.09)$ & 0.09 \\
\hline TT & 1 & - & 1 & - & 1 & - \\
\hline
\end{tabular}

Bold font indicates $p<0.05$; ${ }^{*}$ indicates statistical significance after Bonferroni correction $(p<0.003) .{ }^{\dagger} \mathrm{OR}$ with $95 \%$ CI were estimated by multiple logistic regression models after controlling for age, sex, and smoking. ${ }^{\ddagger} \mathrm{OR}$ with $95 \% \mathrm{CI}$ were estimated by multiple logistic regression models after controlling for age and smoking. 'OR with 95\% CI were estimated by multiple logistic regression models after controlling for age and sex. ${ }^{\mathrm{z}} \mathrm{OR}$ with $95 \% \mathrm{CI}$ were estimated by multiple logistic regression models after controlling for age, considering only females who never smoked. Abbreviations: OR: odds ratio; CI: confidence interval.

in the third base of the 2488 codon. It has been associated with dyslipidemia [22, 39, 40], osteonecrosis [41], and ischemic stroke [23]. Here, we identified the association of $A P O B-$ rs1042031-CT with the lower chance of presenting $\mathrm{P}$ and T2DM concomitantly $(\mathrm{T} 2 \mathrm{DM}+\mathrm{P})$. After the sample stratification by sex or smoking habits, we confirm these findings in females and in never-smoking individuals. Subsequent stratification by gender and smoking status (together) confirmed that $A P O B$-rs1042031-CT females who never smoked had a lower chance to develop T2DM+P $(p=0.004)$. It was reported that the risk of having plaques on carotid arteries was lower in T2DM subjects carrying mutant specific alleles (E-alleles) [42]. The rs676210 SNP is a missense mutation involving $G$ to $A$ substitution that results in the conversion of proline to leucine, also named as Pro2739Leu. The rare allele A at the rs676210 SNP was significantly associated with the increased triglyceridelowering effects of fenofibrate, a drug commonly used to 


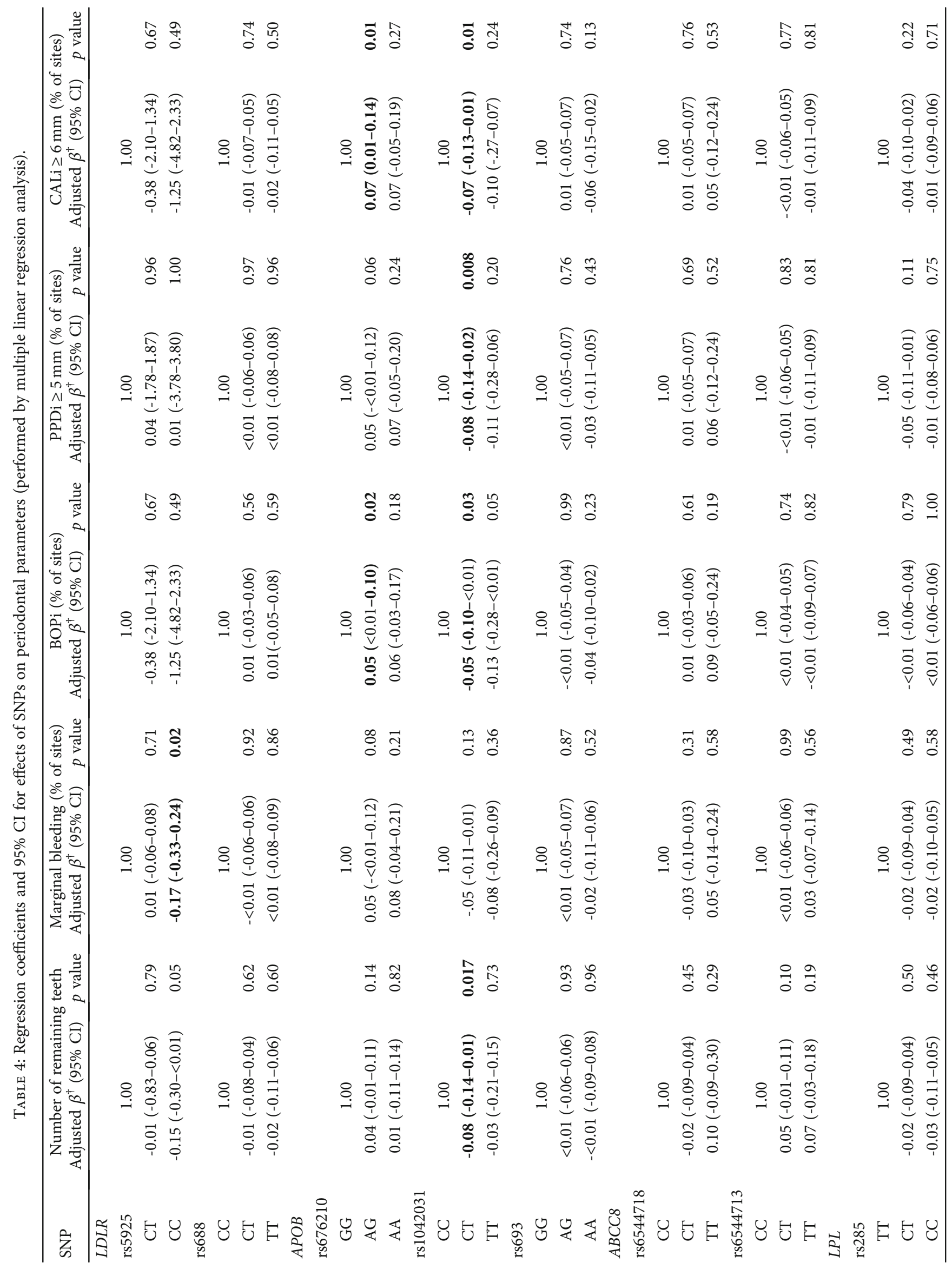




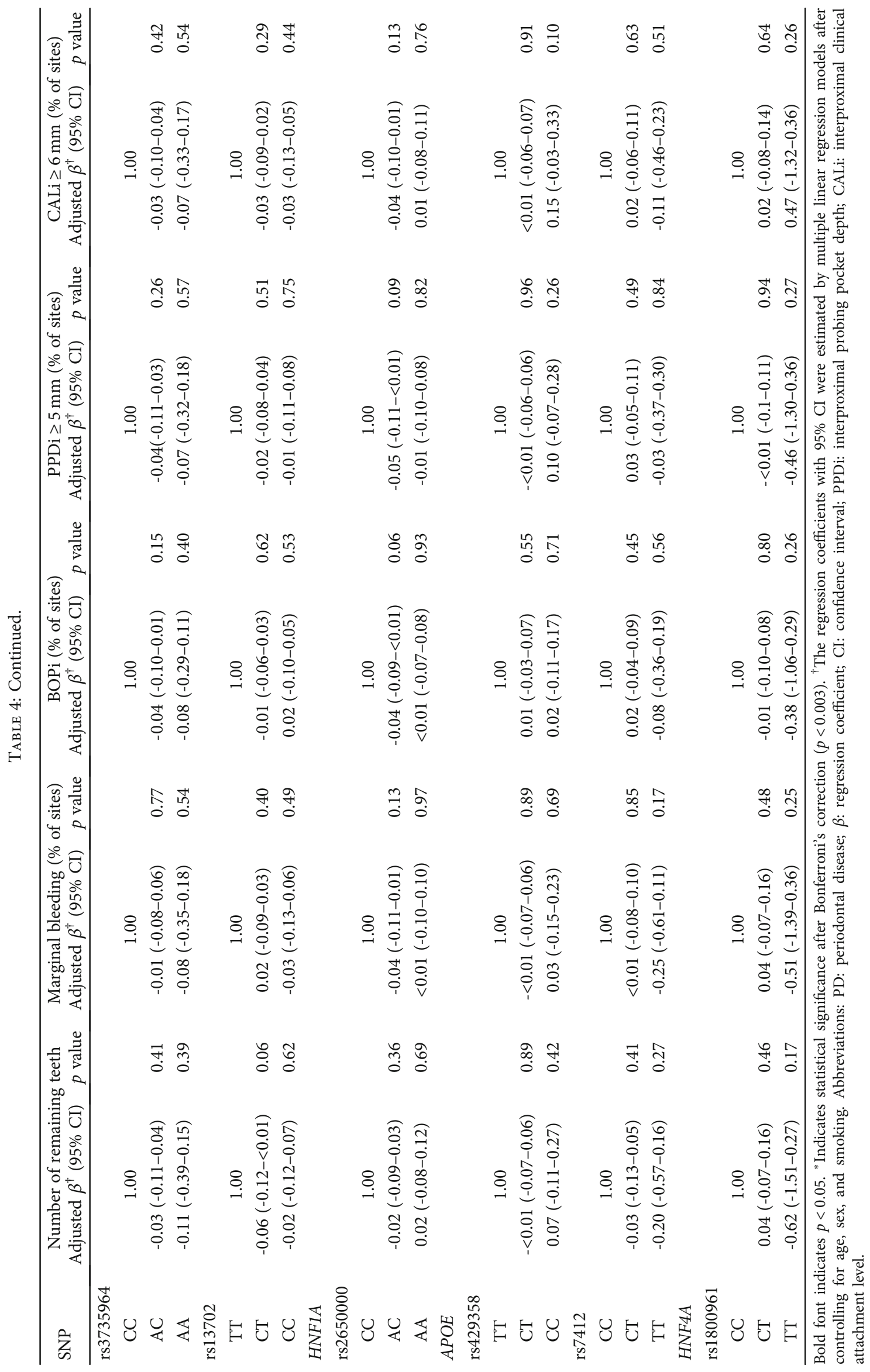




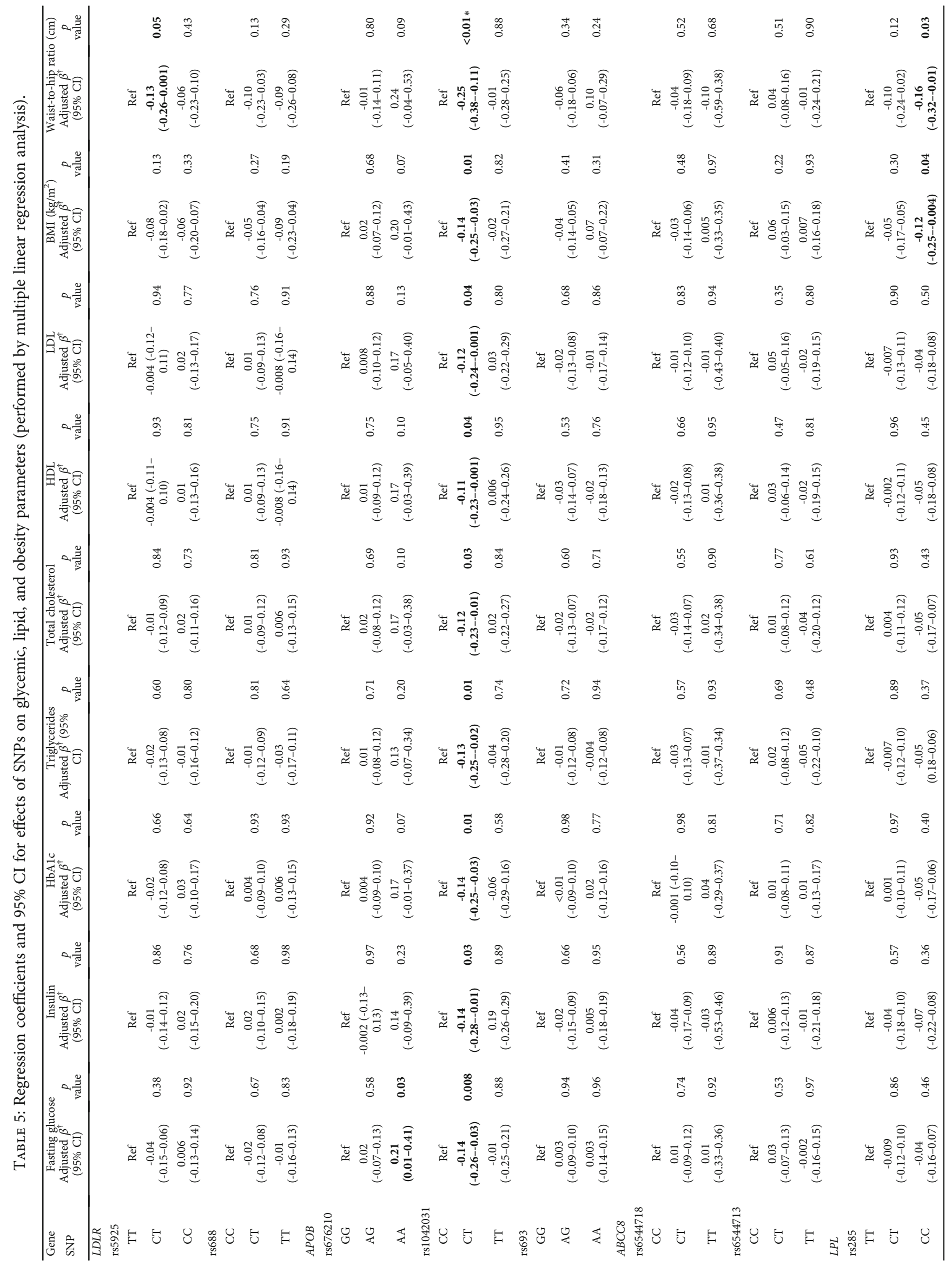




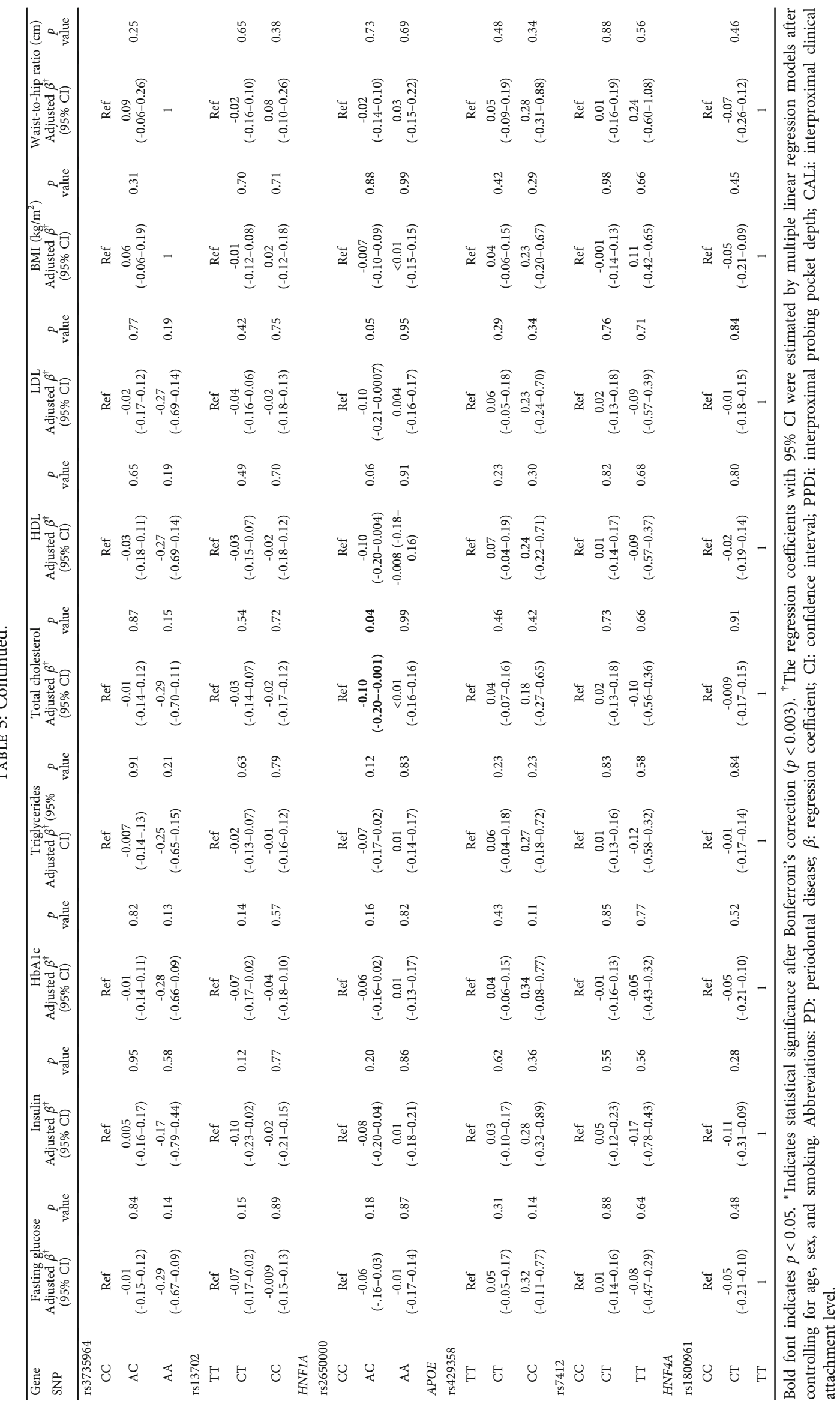


treat hypertriglyceridemia [43], with reduced levels of LDL and triglycerides in Europeans [44]; and GWAS also associated this mutation with increased circulating oxidized LDL (oxLDL) [45]. We identified significant association of the $A P O B$-rs676210-AG with presence of $\mathrm{T} 2 \mathrm{DM}+\mathrm{P}$, whereas the same SNP in homozygosis (rs676210-AA) was associated with increased fasting glucose $(\mathrm{OR}=0.21 ; 95 \% \mathrm{CI}=$ $0.01-0.41 ; p=0.03$, Table 5 ) in our population.

Another relevant result found here was that the poorly controlled with severe periodontitis $\mathrm{T} 2 \mathrm{DM}+\mathrm{P}$ patients showed the highest levels of fasting glucose and HbAlc. It is worth to take into mind that $40 \%$ of the given plasma HbA1c pool reflects glycemia levels of the previous 31-90 days and 10\% during the previous 91-120 days [46, 47] and that hyperglycemia inhibits new bone formation and exacerbates alveolar bone resorption due to periodontal disease [48].

Genetic variants in the ABCC8 gene (OMIM: 600509) have also been widely explored in candidate genes casecontrol studies due to its function of encoding the sulfonylurea receptor, which plays an important role in insulin secretion [49]. Pharmacogenetics studies usually investigate this gene because of its relevance for the efficacy of hypoglycemic drugs, since the failure in oral drug therapy leads to poorly regulated glycemia and dyslipidemia $[24,50]$. Thus, due to the relevance of $A B C C 8$ gene for glycemia in patients with T2DM, it is plausible that this gene may also affect the occurrence and severity of periodontitis in these patients, via poor metabolic control. From the two SNPs investigated in the $A B C C 8$ gene, rs6544718 showed a gender-biased positive association with a lower chance to develop T2DM+P, as men carrying rs6544718-CT were $63 \%$ less likely to develop $\mathrm{T} 2 \mathrm{DM}+\mathrm{P}$. Another gender-biased genetic influence was observed for the LPL gene (OMIM 609708), with men carrying the rs13702-CC SNP presenting increased occurrence of $\mathrm{T} 2 \mathrm{DM}+\mathrm{P}$. Interestingly, in a study enrolling patients affected by only T2DM, Hatefi et al. [25] reported the relationship between this CC genotype with a greater susceptibility to develop T2DM, in agreement with our results. The rs13702-CC may favor the entry of fatty acids into the liver, adipocytes, and skeletal muscle, which leads to the development of insulin resistance and, later, T2DM [25]. Another SNP in the same LPL gene, the rs285-CT, was associated with a lower chance of developing periodontitis. Moreover, the LPL-rs285-CC SNP was also related to the waist-to-hip ratio, as well as to BMI (Table 5).

Polymorphisms in the hepatocyte nuclear factor- $4 \alpha$ (HNF4A) (OMIM: 60028) and HNF1 homeobox A (HNF1A) (OMIM 14210) genes were included in the present study because both genes encode important transcription factors involved in the regulation of lipid and glycemic metabolism [28]. HNF4A has been extensively associated with maturity-onset diabetes of the young (MODY) characterized by deficient pancreatic beta cell insulin secretion [51, 52], which was recently accurately revised by Banday et al. [53]. HNF1A is a transcription factor that interacts with HNF4A and leads to subtypes of MODY and, consequently, increases T2DM susceptibility. This gene resides in the T2DM-linked region on the chromosome 20 which supports a role as a positional candidate gene for the disease [51]. HNF4A-regulated proteins are involved in the pathogenesis of T2DM [54]. Patients with T2DM have been shown to have a characteristic deregulation of lipid metabolism, with lower levels of very low-density lipoprotein (VLDL) [26]. We identified that HNF4A-rs1800961-CT increases the risk of $\mathrm{T} 2 \mathrm{DM}+\mathrm{P}$ almost twofold. These patients are heterozygotes for the rare nonsynonymous mutation T130I (rs1800961). Other SNPs in the HNF4A gene were associated with elevated serum lipid levels and presence of metabolic syndrome, characterized by elevated glucose parameters in dyslipidemic Finnish and Mexican families [27].

There is no consensus regarding the sex-specific susceptibility to complex diseases in humans. Some studies had reported that men had the worst periodontal conditions $[55,56]$, and women with low carbohydrate intake were protected against development of T2DM [49]. Clinical [57], in vitro [58], and in vivo [59] studies have indicated the influence of steroid hormones on inflammation, immune response, and bone metabolism, demonstrating an association of periodontitis with sex hormone levels. More studies specifically designed to assess the sex or smoking habits are necessary to investigate the role of these SNPs in the context of the complex diseases here investigated.

The present case-control study was not age-sex matched, and the absence of a group with subjects affected by only T2DM were limitations of this study. Because of this fact, we are not able to associate a SNP with T2DM as an isolated disease. Since the population studied here was a convenience sample of patients seeking care/referred to the periodontics clinic, it was expected that these subjects were affected by periodontitis. Nevertheless, patients diagnosed by T2DM frequently have periodontitis, which may reflect the difficulty in achieving and sustaining proper metabolic control allowing for the influence of diabetes-related changes in angiogenesis, immune response, and repair mechanisms on the host-microbial interactions in the periodontal microenvironment. In fact, evidence supports that in wellcontrolled T2DM, the extent and severity of periodontitis, as well as the response to treatment, are similar to that of systemically healthy patients. Thus, it is possible that the duration of diabetes (i.e., time since diagnosis) and quality of metabolic control over time may have varied wildly in the studied subjects. Although we had mentioned the use of Bonferroni's correction, we did not strictly consider the $95 \%$ confidence for statistical significance. This was a compromise to reduce the chance of type II error [60-62], which would lead us to reject a true biological association hypothesis. Thus, our results should be interpreted with caution, since some of the $p$ values lower than 0.05 may in fact reflect type I errors (false positives).

Although the sample size allowed for adequate statistical power, it is important to expand the findings on these genetic variants in larger Brazilian populations from different regions of the country and in multiple ethnic populations throughout the world, in agreement with Laine et al. [63] 


\section{Conclusions}

In conclusion, polymorphisms in genes involved in lipid metabolism are associated with susceptibility to the occurrence of T2DM-Periodontitis, with a gene-sex interaction. The APOB-rs1042031 was the most relevant gene marker related to glucose and lipid metabolism profiles, as well as with clinical obesity and periodontitis. Further studies are necessary to confirm these results, investigating the potential functional role of those SNPs at transcriptional and translational levels, and the potential influence of sex in this context.

\section{Data Availability}

The genotypes and biochemical data used to support the findings of this study are included within the article and the supplementary information file.

\section{Conflicts of Interest}

The authors declare that there is no conflict of interest regarding the publication of this paper.

\section{Authors' Contributions}

Ingra G. Nicchio and Thamiris Cirelli are co-first authors.

\section{Acknowledgments}

This study was supported by the Foundation for Research Support of the State of São Paulo-FAPESP (Grants [2014/ 13295-1], [2016/03753-8], [2016/08070-6], and [2016/ 18313-3]) and the National Council for Scientific and Technological Development (CNPq) (Grants [445336/2014-5], [304570/2017-6], and [306073/2020-0]).

\section{Supplementary Materials}

Details of the sample size calculation with the G* Power Calculator, version 3.1.9. Supplementary Table 1: allele and genotype frequencies, minor allele frequency (MAF) analysis, and Hardy-Weinberg equilibrium (HWE). Supplementary Figure 1: results in each group of Spearman's correlations between biochemical profiles and periodontal parameters. Supplementary Table 2: Median (minimummaximum) of glycemic and lipid profiles and physical exams of individuals belonging to the $\mathrm{T} 2 \mathrm{DM}+\mathrm{P}$ subgroups. (Supplementary Materials)

\section{References}

[1] M. S. Tonetti, H. Greenwell, and K. S. Kornman, "Staging and grading of periodontitis: framework and proposal of a new classification and case definition," Journal of Periodontology, vol. 89, Supplement 1, pp. S159-S172, 2018.

[2] M. S. Tonetti, H. Greenwell, and K. S. Kornman, "Staging and grading of periodontitis: framework and proposal of a new classification and case definition," Journal of Clinical Periodontology, vol. 45, Supplement 20, pp. S149-S161, 2018.
[3] V. Baelum and R. Lopez, "Periodontal epidemiology: towards social science or molecular biology?," Community Dentistry and Oral Epidemiology, vol. 32, no. 4, pp. 239-249, 2004.

[4] R. C. Page and P. I. Eke, "Case definitions for use in population-based surveillance of periodontitis," Journal of Periodontology, vol. 78, no. 7s, pp. 1387-1399, 2007.

[5] American Diabetes, A, "Diagnosis and classification of diabetes mellitus," Diabetes Care, vol. 37, Supplement 1, pp. S81S90, 2014.

[6] K. Alberti, P. Zimmet, and WHO Consultation, "Definition, diagnosis and classification of diabetes mellitus and its complications. Part 1: diagnosis and classification of diabetes mellitus. Provisional Report of a WHO consultation," Diabetic Medicine, vol. 15, no. 7, pp. 539-553, 1998.

[7] American Diabetes, A, "Classification and diagnosis of Diabetes:Standards of medical care in diabetes-2019," Diabetes Care, vol. 42, Supplement 1, pp. S13-S28, 2019.

[8] G. G. Nascimento, F. R. M. Leite, P. Vestergaard, F. Scheutz, and R. López, "Does diabetes increase the risk of periodontitis? A systematic review and meta-regression analysis of longitudinal prospective studies," Acta Diabetologica, vol. 55, no. 7, pp. 653-667, 2018.

[9] B. L. Mealey and T. W. Oates, "Diabetes mellitus and periodontal diseases," Journal of Periodontology, vol. 77, no. 8, pp. 1289-1303, 2006.

[10] L. Kopin and C. Lowenstein, "Dyslipidemia," Annals of Internal Medicine, vol. 167, no. 11, pp. ITC81-ITC96, 2017.

[11] A. D. Kaze, P. Santhanam, S. K. Musani, R. Ahima, and J. B. Echouffo-Tcheugui, "Metabolic dyslipidemia and cardiovascular outcomes in type 2 diabetes mellitus: findings from the look AHEAD study," Journal of the American Heart Association, vol. 10, no. 7, article e016947, 2021.

[12] M. R. Taskinen, “Type 2 diabetes as a lipid disorder," Current Molecular Medicine, vol. 5, no. 3, pp. 297-308, 2005.

[13] American Diabetes, A, "Standards of medical care in diabetes2013," Diabetes Care, vol. 36, Supplement_1, pp. S11-S66, 2013.

[14] R. Nepomuceno, S. C. Pigossi, L. S. Finoti et al., "Serum lipid levels in patients with periodontal disease: a meta-analysis and meta-regression," Journal of Clinical Periodontology, vol. 44, no. 12, pp. 1192-1207, 2017.

[15] X. Zhou, W. Zhang, X. Liu, W. Zhang, and Y. Li, “Interrelationship between diabetes and periodontitis: role of hyperlipidemia," Archives of Oral Biology, vol. 60, no. 4, pp. 667-674, 2015.

[16] P. M. Preshaw, A. L. Alba, D. Herrera et al., "Periodontitis and diabetes: a two-way relationship," Diabetologia, vol. 55 , no. 1 , pp. 21-31, 2012.

[17] A. S. Schaefer, "Genetics of periodontitis: discovery, biology, and clinical impact," Periodontology 2000, vol. 78, no. 1, pp. 162-173, 2018.

[18] N. Kaul and S. Ali, "Genes, genetics, and environment in type 2 diabetes: implication in personalized medicine," DNA and Cell Biology, vol. 35, no. 1, pp. 1-12, 2016.

[19] M. L. Matey-Hernandez, F. M. K. Williams, T. Potter, A. M. Valdes, T. D. Spector, and C. Menni, "Genetic and microbiome influence on lipid metabolism and dyslipidemia," Physiological Genomics, vol. 50, no. 2, pp. 117-126, 2018.

[20] J. Almeida Abdo, F. R. Cirano, M. Z. Casati et al., "Influence of dyslipidemia and diabetes mellitus on chronic periodontal 
disease," Journal of Periodontology, vol. 84, no. 10, pp. 14011408, 2013.

[21] S. Kathiresan, C. J. Willer, G. M. Peloso et al., "Common variants at 30 loci contribute to polygenic dyslipidemia," Nature Genetics, vol. 41, no. 1, pp. 56-65, 2009.

[22] J. Bentzen, T. Jorgensen, and M. Fenger, "The effect of six polymorphisms in the apolipoprotein B gene on parameters of lipid metabolism in a Danish population," Clinical Genetics, vol. 61, no. 2, pp. 126-134, 2002.

[23] A. Au, L. R. Griffiths, L. Irene, C. W. Kooi, and L. K. Wei, "The impact of $A P O A 5, A P O B, A P O C 3$ and $A B C A 1$ gene polymorphisms on ischemic stroke: Evidence from a meta-analysis," Atherosclerosis, vol. 265, pp. 60-70, 2017.

[24] N. Nikolac, A. M. Simundic, A. Saracevic, and D. Katalinic, "ABCC8Polymorphisms are associated with triglyceride concentration in type 2 diabetics on sulfonylurea therapy," Genetic Testing and Molecular Biomarkers, vol. 16, no. 8, pp. 924-930, 2012.

[25] Z. Hatefi, G. Soltani, S. Khosravi, M. Kazemi, A. R. Salehi, and R. Salehi, "Micro R-410 binding site single nucleotide polymorphism rs13702 in lipoprotein lipase gene is effective to increase susceptibility to type 2 diabetes in Iranian population," Advanced Biomedical Research, vol. 7, no. 1, p. 79, 2018.

[26] V. Marcil, D. Amre, E. G. Seidman et al., "Hepatocyte nuclear factor 4 alpha polymorphisms and the metabolic syndrome in French-Canadian youth," PLoS One, vol. 10, no. 2, article e0117238, 2015.

[27] D. Weissglas-Volkov, A. Huertas-Vazquez, E. Suviolahti et al., "Common hepatic nuclear Factor-4 Variants Are Associated With High Serum Lipid Levels and the metabolic syndrome," Diabetes, vol. 55, no. 7, pp. 1970-1977, 2006.

[28] K. W. Huang, V. Reebye, K. Czysz et al., "Liver Activation of Hepatocellular Nuclear Factor- $4 \alpha$ by Small Activating RNA Rescues Dyslipidemia and Improves Metabolic Profile," Molecular Therapy Nucleic Acids, vol. 19, pp. 361-370, 2020.

[29] F. Faul, E. Erdfelder, A. G. Lang, and A. Buchner, "G* Power 3: a flexible statistical power analysis program for the social, behavioral, and biomedical sciences," Behavior Research Methods, vol. 39, no. 2, pp. 175-191, 2007.

[30] B. G. Nordestgaard, A. Langsted, S. Mora et al., "Fasting is not routinely required for determination of a lipid profile: clinical and laboratory implications including flagging at desirable concentration cut-points-a joint consensus statement from the European Atherosclerosis Society and European Federation of Clinical Chemistry and Laboratory Medicine," European Heart Journal, vol. 37, no. 25, pp. 1944-1958, 2016.

[31] American Diabetes, A, "Glycemic Targets:Standards of medical care in diabetes-2019," Diabetes Care, vol. 42, Supplement 1, pp. S61-S70, 2019.

[32] T. Cirelli, R. Nepomuceno, S. R. P. Orrico et al., "Validation in a Brazilian population of gene markers of periodontitis previously investigated by GWAS and bioinformatic studies," Journal of Periodontology, vol. 92, no. 5, pp. 689-703, 2021.

[33] T. Cirelli, R. Nepomuceno, A. C. S. Rios et al., "Genetic polymorphisms in theInterleukins IL1B, IL4, andIL6are associated with concomitant periodontitis and type 2 diabetes mellitus in Brazilian patients," Journal of Periodontal Research, vol. 55, no. 6, pp. 918-930, 2020.

[34] Y. Miyake, K. Tanaka, and M. Arakawa, "IL3rs40401 polymorphism and interaction with smoking in risk of asthma in Japanese women: the Kyushu Okinawa Maternal and Child
Health study," Scandinavian Journal of Immunology, vol. 79, no. 6, pp. 410-414, 2014.

[35] M. Aidar and S. R. Line, "A simple and cost-effective protocol for DNA isolation from buccal epithelial cells," Brazilian Dental Journal, vol. 18, no. 2, pp. 148-152, 2007.

[36] S. Purcell, B. Neale, K. Todd-Brown et al., "PLINK: a tool set for whole-genome association and population-based linkage analyses," American Journal of Human Genetics, vol. 81, no. 3, pp. 559-575, 2007.

[37] J. Rajput-Williams, S. C. Wallis, J. Yarnell et al., "Variation of apolipoprotein-B gene is associated with obesity, high blood cholesterol levels, and increased risk of coronary heart disease," The Lancet, vol. 332, no. 8626-8627, pp. 1442-1446, 1988.

[38] S. A. al-Bustan, M. A. Alnaqeeb, B. G. Annice, G. A. Ebrahim, and T. M. Refai, "Genetic association of APOB polymorphisms with variation in serum lipid profile among the Kuwait population," Lipids in Health and Disease, vol. 13, no. 1, p. 157, 2014.

[39] K. Tsunoda, S. Harihara, Y. Tanabe, and B. Dashnyam, "Polymorphism of the apolipoprotein B gene and association with plasma lipid and lipoprotein levels in the Mongolian Buryat," Biochemical Genetics, vol. 50, no. 3-4, pp. 249-268, 2012.

[40] P. Hu, Y. H. Qin, C. X. Jing, L. Lu, B. Hu, and P. F. du, "Effect of apolipoprotein B polymorphism on body mass index, serum protein and lipid profiles in children of Guangxi, China," Annals of Human Biology, vol. 36, no. 4, pp. 411-420, 2009.

[41] Y. Hao, H. Guo, Z. Xu et al., “The relationship between apolipoprotein genes polymorphisms and susceptibility to osteonecrosis of the femoral head: a meta-analysis," Lipids in Health and Disease, vol. 17, no. 1, p. 192, 2018.

[42] J. Nikolajevic Starcevic, M. Santl Letonja, Z. J. Praznikar, J. Makuc, A. C. Vujkovac, and D. Petrovic, "Polymorphisms XbaI (rs693) and EcoRI (rs1042031) of the ApoB gene are associated with carotid plaques but not with carotid intimamedia thickness in patients with diabetes mellitus type 2," VASA, vol. 43, no. 3, pp. 171-180, 2014.

[43] M. K. Wojczynski, G. Gao, I. Borecki et al., “Apolipoprotein B genetic variants modify the response to fenofibrate: a GOLDN study[S]," Journal of Lipid Research, vol. 51, no. 11, pp. 33163323, 2010.

[44] E. J. Barbosa, C. A. M. Glad, A. G. Nilsson et al., "Genotypes associated with lipid metabolism contribute to differences in serum lipid profile of GH-deficient adults before and after GH replacement therapy," European Journal of Endocrinology, vol. 167, no. 3, pp. 353-362, 2012.

[45] K. M. Mäkelä, I. Seppälä, J. A. Hernesniemi et al., "Genomewide association study pinpoints a new functional apolipoprotein B variant influencing oxidized low-density lipoprotein levels but not cardiovascular Events," Circulation. Cardiovascular Genetics, vol. 6, no. 1, pp. 73-81, 2013.

[46] L. Heinemann, "HbAlc-glycated hemoglobin and diabetes mellitus: a book review," Journal of Diabetes Science and Technology, vol. 4, no. 2, pp. 494-495, 2010.

[47] A. S. Sameer, M. Z. Banday, S. Nissar, and S. A. Saeed, “A comparison of biomarkers in the assessment of glycemic control in diabetes: reviewing the evidence," Current Diabetes Reviews, vol. 15, no. 6, pp. 471-479, 2019.

[48] X. Wang, H. Wang, T. Zhang, L. Cai, C. Kong, and J. He, "Current knowledge regarding the interaction between oral bone 
metabolic disorders and diabetes mellitus," Frontiers in Endocrinology, vol. 11, p. 536, 2020.

[49] U. Ericson, G. Rukh, I. Stojkovic et al., "Sex-specific interactions between the IRS1 polymorphism and intakes of carbohydrates and fat on incident type 2 diabetes," The American Journal of Clinical Nutrition, vol. 97, no. 1, pp. 208-216, 2013.

[50] S. E. Flanagan, S. Clauin, C. Bellanné-Chantelot et al., "Update of mutations in the genes encoding the pancreatic beta-cell KATPchannel subunits Kir6.2 (KCNJ11) and sulfonylurea receptor 1 (ABCC8) in diabetes mellitus and hyperinsulinism," Human Mutation, vol. 30, no. 2, pp. 170-180, 2009.

[51] A. M. Bagwell, J. L. Bento, J. C. Mychaleckyj, B. I. Freedman, C. D. Langefeld, and D. W. Bowden, "Genetic analysis of HNF4A polymorphisms in Caucasian-American type 2 diabetes," Diabetes, vol. 54, no. 4, pp. 1185-1190, 2005.

[52] D. Q. Shih, H. M. Dansky, M. Fleisher, G. Assmann, S. S. Fajans, and M. Stoffel, "Genotype/phenotype relationships in HNF-4alpha/MODY1: haploinsufficiency is associated with reduced apolipoprotein (AII), apolipoprotein (CIII), lipoprotein(a), and triglyceride levels," Diabetes, vol. 49, no. 5, pp. 832-837, 2000.

[53] M. Z. Banday, A. S. Sameer, and S. Nissar, "Pathophysiology of diabetes: an overview," Avicenna Journal of Medicine, vol. 10, no. 4, pp. 174-188, 2020.

[54] K. Silander, K. L. Mohlke, L. J. Scott et al., "Genetic variation near the hepatocyte nuclear Factor-4 Gene Predicts Susceptibility to type 2 diabetes," Diabetes, vol. 53 , no. 4 , pp. 11411149, 2004.

[55] J. M. Albandar, "Global risk factors and risk indicators for periodontal diseases," Periodontology 2000, vol. 29, no. 29, pp. 177-206, 2002.

[56] G. Anovazzi, Y. J. Kim, A. C. Viana et al., "Polymorphisms and haplotypes in theInterleukin-4Gene are associated with chronic periodontitis in a Brazilian population," Journal of Periodontology, vol. 81, no. 3, pp. 392-402, 2010.

[57] P. Meisel, T. Krause, I. Cascorbi et al., "Gender and smokingrelated risk reduction of periodontal disease with variant myeloperoxidase alleles," Genes and Immunity, vol. 3, no. 2, pp. 102-106, 2002.

[58] D. J. Lee, L. Wu, M. Shimono et al., "Differential mechanism of periodontitis progression in postmenopause," Frontiers in Physiology, vol. 9, p. 1098, 2018.

[59] J. P. Steffens, X. Wang, J. R. Starr, L. C. Spolidorio, T. E. van Dyke, and A. Kantarci, "Associations between sex hormone levels and periodontitis in men: results from NHANES III," Journal of Periodontology, vol. 86, no. 10, pp. 1116-1125, 2015.

[60] D. G. Bussaneli, M. Restrepo, C. M. B. Fragelli et al., "Genes regulating immune response and amelogenesis interact in increasing the susceptibility to molar-incisor hypomineralization," Caries Research, vol. 53, no. 2, pp. 217-227, 2019.

[61] M. M. Uhlen, K. R. Stenhagen, P. M. Dizak et al., "Genetic variation may explain why females are less susceptible to dental erosion," European Journal of Oral Sciences, vol. 124, no. 5, pp. 426-432, 2016.

[62] A. R. Vieira, M. Bayram, F. Seymen, R. C. Sencak, F. Lippert, and A. Modesto, "In vitro acid-mediated initial dental enamel loss is associated with genetic variants previously linked to caries experience," Frontiers in Physiology, vol. 8, p. 104, 2017.

[63] M. L. Laine, S. Jepsen, and B. G. Loos, "Progress in the identification of genetic factors in periodontitis," Current Oral Health Reports, vol. 1, no. 4, pp. 272-278, 2014. 